\title{
Estratégia\&Negócios
}

ISSN 1984-3372

http://www.portaldeperiodicos.unisul.br/index.php/EeN/

\section{FATORES DETERMINANTES DA MORTALIDADE DE MICRO E PEQUENAS EMPRESAS DA REGIÃO METROPOLITANA DE FLORIANÓPOLIS SOB A ÓTICA DO CONTADOR}

\section{DECISIVE FACTORS TO MORTALITY OF MICRO AND SMALL COMPANIES IN THE METROPOLITAN AREA OF FLORIANOPOLIS FROM THE STANDPOINT OF THE ACCOUNTANT}

\author{
Marcelo Nascimento \\ Coordenador do Curso em Ciências Contábeis e professor da Faculdade Borges de Mendonça e professor do Centro \\ Universitário Anhanguera \\ E-mail: marcelo.nascimento@bm.edu.br
}

\section{Carlos Rogério Montenegro de Lima}

Professor do Programa de Pós-Graduação em Administração - Mestrado da Universidade do Sul de Santa Catarina E-mail: carlos.montenegro@unisul.br

\section{Mauricio Andrade de Lima}

Professor do Programa de Pós-Graduação em Administração - Mestrado da Universidade do Sul de Santa Catarina E-mail: $\underline{\text { mauricio.lima@unisul.br }}$

\section{Eduardo Rolim Ensslin}

Mestre em Engenharia de Produção pela Universidade Federal de Santa Catarina.

E-mail: eduardo ensslin@hotmail.com

Recebido em 07/04/2013. Aprovado em 04/08/2013. Disponibilizado em 30/08/2013.

Avaliado pelo Sistema double blind review

R. eletr. estrat. neg., Florianópolis, v.6, n.2, p. 244-283, mai./ago. 2013

http://portaldeperiodicos.unisul.br/index.php/EeN/index
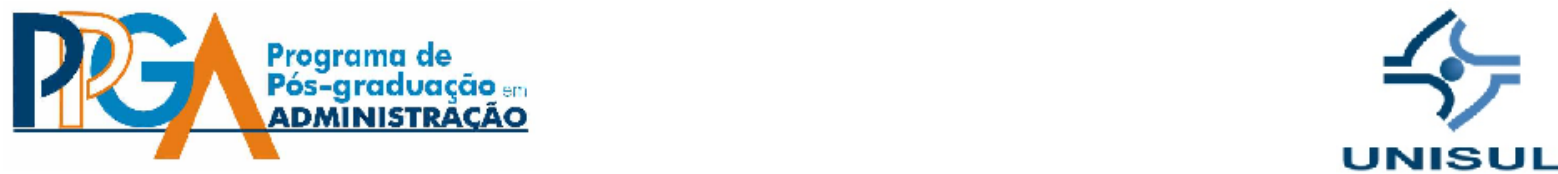

CCopyright 2008 UNISUL-PPGA/Estratégia e Negócios. Todos os direitos reservados. Permitida citação parcial, desde que identificada a fonte. Proibida a reprodução total. Em caso de dúvidas, consulte o editor:

ademar.unisul@gmail.com; (48) 3229-19 


\section{RESUMO}

O objetivo deste artigo é analisar sob a ótica do contador os fatores determinantes para a mortalidade precoce das micro e pequenas empresas na cidade de Florianópolis. A fim de obter maiores informações sobre os aspectos que levam as empresas a sucumbirem, foi realizada uma pesquisa quantitativa. Para a coleta de dados, foi aplicado um questionário junto a 141 contadores de escritórios da região metropolitana de Florianópolis. Foi possível identificar que a maioria dos fatores citados pela literatura especializada apresenta o mesmo grau de importância sob a ótica do contador. Porém, dois fatores verificados na literatura especializada não foram considerados determinantes sob a ótica do contador para a falência das MPEs, a saber: o nível de escolaridade do empreendedor e a carga tributária.

Palavras-chave: Falência. Micro e pequenas empresas. Contador.

\section{INTRODUÇÃO}

As pequenas e médias empresas (MPEs) são fundamentais para promover o crescimento econômico, criar empregos e renda e melhorar as condições de vida da população. Os indicadores desse segmento empresarial demonstram sua importância na economia, não só no Brasil, mas em todo o mundo.

Segundo o Portal Brasil (2012), a contribuição das MPEs é reconhecida principalmente pela capilaridade que esses negócios propiciam e pela absorção de mão de obra, inclusive aquela com maior dificuldade de inserção no mercado, como jovens em busca pelo primeiro emprego e pessoas com mais de 40 anos.

As pequenas empresas também são capazes de dinamizar a economia dos municípios e bairros das grandes metrópoles. Na economia brasileira, segundo o Instituto Brasileiro de Geografia e Estatística (IBGE, 2003), elas representam cerca de $20 \%$ do Produto Interno Bruto (PIB) e $60 \%$ dos postos de trabalho de um total de 56,4 milhões. Também, segundo o Anuário do Trabalho na Micro e Pequena Empresa (SEBRAE, 2006), no Brasil, as MPEs representavam 99,0\% do total de empresas constituídas no país. 
Desde 2000, a participação das MPEs no total de empreendimentos produtivos brasileiros vem crescendo. Enquanto a taxa de crescimento anual foi de $4 \%$ para o total de empresas, independente do porte, para as pequenas empresas foi de $6,2 \%$, e $3,8 \%$ para as micros, entre 2000 e 2008. Nesse mesmo período, as MPEs foram responsáveis por aproximadamente metade dos postos e trabalho formais criados, ou seja, 4,5 milhões de empregos (PORTAL BRASIL, 2012).

O faturamento das MPEs também cresceu consideravelmente nos últimos anos. No primeiro semestre de 2010, a receita real registrou aumento de $10,7 \%$ comparado ao mesmo período de 2009. Esse indicador aponta que as pequenas empresas superam o ritmo de crescimento da economia brasileira. Essa é a maior taxa de crescimento de faturamento desde que o Serviço Brasileiro de Apoio às Micro e Pequenas Empresas (SEBRAE) iniciou a pesquisa, em 1998 (PORTAL BRASIL, 2012).

Entretanto, apesar da importância das MPEs para a economia e para o desenvolvimento regional, é possível verificar altos índices de mortalidade precoce de micro e pequenas empresas gerados por vários fatores. De acordo com pesquisa realizada pelo SEBRAE (2004), 22\% dessas empresas decretaram falência antes de completar os dois primeiros anos de existência e 58\% delas fecharam as portas antes de completarem cinco anos. Outra pesquisa realizada no Brasil pelo SEBRAE (2008) mostrou que até o ano de 2005, a metade dos empreendimentos fechava suas portas antes de completar dois anos.

Conforme a Serasa Experian (2010), que divulga mensalmente dados sobre falências e recuperações de empresas no território nacional, no primeiro trimestre do ano de 2010, houve um aumento no pedido de falência das grandes empresas de 6,9\% comparado com o primeiro trimestre de 2009. Um dos motivos explanados foi que esse aumento pudesse estar relacionado à demanda externa que ainda não havia se recuperado plenamente da crise financeira internacional, iniciada em setembro de 2008.

Outra pesquisa do SEBRAE (2004) aponta que no período de 2000 a 2002 houve o fechamento de 770 mil empresas, causando a perda de 2,4 milhões de postos de trabalho, contribuindo para o crescimento das taxas de desemprego e da atividade informal, ou seja, a insolvência traz muitas implicações para a região onde se localizam. 
Nesse contexto, vários fatores são apontados como determinantes para esses índices e são amplamente discutidos por Adizes (1990), Birley e Niktari (1996), Yonemoto (1998), Alves et al. (1999), Gomes (2000), Clevery (2002), Felippe (2003), Mai (2006), Filardi (2006), Ortigara (2006), Cardoso (2007), Da Silva (2002; 2008), Ribeiro Neto (2008), Cunha Junior (2009) e Pazolini (2011). Tais estudos confirmam que as empresas mais atingidas pela insolvência precoce no Brasil são as pequenas e médias empresas.

Azevedo (1992) ressalta que as estatísticas oficiais referentes à extinção das empresas não expressam a realidade brasileira, pois muitos negócios fecham as suas portas sem dar baixa nas instituições de registros oficiais. Segundo o autor, $50 \%$ das pequenas empresas abertas no Brasil não sobrevivem ao primeiro ano, e nem todas que não superam essa marca fracassam, pois algumas são compradas ou fecham para se transformar em um novo negócio.

Em Santa Catarina, analisando os relatórios da Junta Comercial do Estado de Santa Catarina (JUCESC, 2010), observa-se certa frequência nos números de falência e extinção de empresas. Poucos estudos decorrem especificamente sobre o Estado, diferente de outros Estados, como São Paulo e Minas Gerais, onde existem alguns trabalhos publicados sobre o tema.

Ortigara (2006) corrobora com Azevedo (1992) ressaltando que pouco mais da metade das empresas extintas $(53,85 \%)$ comunicaram à JUCESC para efetuar a baixa da referida organização. Tal fato confirma que muitas empresas extintas e falidas deixam de informar, aos órgãos responsáveis, que realizaram o fim de suas entidades.

Lima, Filardi e Lopes (2009) afirmam que no Brasil há carência de muitos estudos sobre MPEs, diferentemente de outros países, que realizam pesquisas periódicas sobre a insolvência dessas empresas. À frente dos estudos, com aplicação de metodologia de pesquisa científica sobre a mortalidade de MPEs, estão os Estados Unidos.

Silva (1999) afirma que, embora todas as empresas estejam inseridas em ambientes idênticos, compostos pelos mesmos fatores internos e externos, e possam compartilhar problemas conjunturais equivalentes, detêm condições diferentes de reagir, demonstrando diferenças significativas de desempenho. Portanto, a necessidade de criação de instrumentos capazes de diminuir os índices de mortalidade empresarial, ajudando cada 
vez mais o gestor, seja com ferramentas gerenciais ou com resultados de análises de outros casos de falência, ganham significância para evitar que tais índices se repitam.

Nesse contexto, este artigo tem como objetivo geral analisar sob a ótica do contador os fatores determinantes para a mortalidade precoce das micro e pequenas empresas na região metropolitana de Florianópolis.

A contribuição desta pesquisa na área acadêmica é buscar informações sobre os fatores determinantes de falência nas empresas junto aos escritórios de contabilidade, pois estes convivem diariamente com os empresários e mostram sob outra ótica quais são os fatores que contribuem para o fim de uma organização de micro e pequeno porte.

$\mathrm{Na}$ área prática, seus resultados vão ao encontro das demandas dos gestores desses empreendimentos, pois se caracteriza e se descreve de forma objetiva quais os fatores que mais influenciam na insolvência das PMEs e, por fim, de forma indireta, ajuda-se a sociedade em relação ao desemprego, à renda e à produção.

Para que se atendesse ao seu objetivo, este artigo foi estruturado em seis seções. A primeira apresentará a introdução de forma a contextualizar o tema, o problema da pesquisa, os objetivos e a justificativa. Na segunda seção, será apresentada a fundamentação teórica, com a revisão da literatura e dos trabalhos já estudados pertinentes ao tema e que serão a base para o entendimento do restante do texto. Na terceira seção, serão discutidos os procedimentos metodológicos a serem empregados neste artigo. A apresentação e análise dos dados, por sua vez, farão parte da quarta seção. Na quinta seção, serão apresentadas as considerações finais e, por fim, na última seção, as referências.

\section{REFERENCIAL TEÓRICO}

\subsection{EMPREENDEDOR E EMPREENDEDORISMO}

Em um contexto internacional, o interesse pelo empreendedorismo, pode ser entendido, por meio do estudo dos números da economia americana, considerando que o governo federal americano investe anualmente em programas de apoio ao empreendedorismo e incentiva diversas iniciativas de governos estaduais e de organizações 
privadas que fomentam novas empresas no país. Por esse motivo, essas iniciativas têm sido vistas como modelo por outros países que buscam aumentar o nível de sua atividade empresarial, como é o caso da Inglaterra, que criou em 1999 a Agência de Serviços para Pequenas Empresas, baseada em institutos semelhantes que surgiram nos Estados Unidos (FILARDI, 2006).

Segundo Passos et al. (2008), o Brasil vem demonstrando, nos últimos anos, a grande capacidade empreendedora de sua população ao atingir uma Taxa de Atividade Empreendedora (TAE) de 12,72\% da População Economicamente Ativa (PEA) em 2007. Confirmando o que Passos et al. (2008) já haviam exposto, a TAE de 2009 se manteve na média de 12\%, segundo a pesquisa do Global Entrepreneurship Monitor (GEM, 2009). Ao se comparar esse valor à média da TAE para os países que participaram de todas as coletas de 2001 a 2009, pode-se observar que a taxa média brasileira permanece acima da média mundial, ou seja, a população brasileira é em média $85 \%$ mais empreendedora do que o grupo de países que participaram de todas as edições da Pesquisa GEM de 2001 a 2009.

Para Harper (2008), no nível mais básico, o empreendedorismo envolve a descoberta e a criação de novas soluções e finalidades. Ainda, segundo o mesmo autor, a descoberta empreendedora é definida como um processo de solução de problemas de busca por lucro que acontece em condições de incerteza estrutural, exigindo o exercício de imaginação e julgamento crítico na identificação de problemas (oportunidades) e na geração de soluções para serem testadas.

Autores como Degen (1989), Dolabela (1999), Dutra (2002) e Santos e Pereira (1995) destacam a importância do desenvolvimento do potencial empreendedor e da aplicação da função gerencial na administração de empresas empreendedoras como contextos importantes para o sucesso das mesmas. Porém, algumas razões de base socioeconômica de não longevidade dos negócios são apontadas por Alves et al. (1999), Dutra (2002) e Vale et al (1998), entre elas destaca-se a ausência da gestão previsional, identificada pela inexistência ou deficiência do planejamento do negócio, também observada por Zimmerer e Scarborough (1998), e pela fraca aplicação prática dos métodos de boa gestão. 
Com esses conceitos, percebe-se a importância do empreendedorismo no meio econômico, social e até cultural de uma região. Evidenciando esse fato, Tachizawa e Faria (2002) relatam que os empreendedores são pessoas que fazem acontecer, que desenvolvem sua capacidade de superar limites, ou seja, fazem a diferença. Sem essas pessoas, portanto, não haveria desenvolvimento mundial, por isso essas características devem ser potencializadas.

\subsection{MICRO E PEQUENAS EMPRESAS}

As empresas brasileiras são classificadas segundo seu porte, existindo duas formas clássicas. Uma pela legislação tributária brasileira e outra pelo modelo estabelecido pelo IBGE, classificando as empresas segundo o número de funcionários combinado com o setor de atuação da empresa.

O regime simplificado de tributação (SIMPLES), que é uma lei de cunho estritamente tributário, adota um critério diferente para enquadrar micro e pequena empresa. O Simples Nacional foi instituído pela Lei Complementar no 123, de 2006, e os critérios utilizados estão dispostos no Quadro 1, a seguir.

Quadro 1 - Classificação das empresas de acordo com o Faturamento

\begin{tabular}{|l|l|}
\hline \multicolumn{1}{|c|}{ Porte } & \multicolumn{1}{c|}{ Faturamento em R\$ } \\
\hline Microempresa & Receita bruta anual igual ou inferior a $\mathrm{R} \$ 240.000,00$. \\
\hline $\begin{array}{l}\text { Empresa de } \\
\text { Pequeno Porte }\end{array}$ & Receita bruta anual superior a $\mathrm{R} \$ 240.000,00$ e igual ou inferior a $\mathrm{R} \$ 2.400 .000,00$. \\
\hline
\end{tabular}

Fonte: Lei Complementar no123/, (2006).

O Quadro 2, a seguir, mostra o critério adotado pelo SEBRAE para classificação das empresas:

Quadro 2 - Classificação das empresas segundo o número de funcionários

\begin{tabular}{|l|l|l|}
\hline \multirow{2}{*}{ Porte } & \multicolumn{2}{|l|}{ Número de Empregados por Tipo de Empresa } \\
\cline { 2 - 3 } & Indústria & Comércio e Serviços \\
\hline Microempresa & Até 19 funcionários & Até 09 funcionários \\
\hline Pequena Empresa & Empresa de 20 a 99 funcionários & De 10 a 49 funcionários \\
\hline
\end{tabular}

Fonte: SEBRAE, (2010b).

R. eletr. estrat. neg., Florianópolis, v.6, n.2, p. 244-283, mai./ago. 2013 
Meira Neto (2003) descreve que as MPEs atuam geralmente em setores mais tradicionais da economia, como o comércio varejista e de serviços. Uma pesquisa realizada pelo SEBRAE (2010) aponta que as micro e pequenas empresas foram responsáveis por 71,3\% do saldo líquido de empregos gerados em maio de 2010. Uma grande parte desse desempenho $(48,0 \%)$ foi fruto das contratações nos empreendimentos que empregam até 4 trabalhadores, seguido daqueles que empregam entre 20 e 99 trabalhadores e que participaram com 13,8\% do saldo total. Esse fato, por si só, já demonstra a importância desse segmento no país.

Para Koteski (2004), as micro e pequenas empresas são um dos principais pilares de sustentação da economia brasileira, quer pela sua enorme capacidade geradora de empregos, quer pelo infindável número de estabelecimentos desconcentrados geograficamente.

\subsection{ESTUDO SOBRE A MORTALIDADE DE EMPRESAS NO BRASIL E NO MUNDO}

O estudo das causas de mortalidade precoce da MPE é fruto de várias pesquisas. Um exemplo é a pesquisa desenvolvida por Davis (1939), que já em meados dos anos 30 realizava estudos os quais mostravam que em algumas cidades dos Estados Unidos a mortalidade dessas empresas atingia um índice de $77,6 \%$ ao final do terceiro ano. Dessa pesquisa, surgiram alguns fatores pelo alto índice de mortalidade como: carência de mão de obra especializada, falta de infraestrutura, instabilidade política e econômica e dificuldade de se adaptar às rápidas mudanças dos consumidores.

No início da década de 1980, Cochran (1981) identificou que a falta de competência gerencial e a falta de experiência no ramo de negócio são os principais fatores contribuintes para mortalidade prematura dessas empresas. Já no final da década de 1980, oito anos mais tarde, Holmes e Haswell (1989) comprovaram que das 418 MPEs estudadas na Austrália, entre os anos de 1981 e 1985, 90\% tiveram sua morte associada a um dos dois fatores citados por Cochran (1981).

Para Borinelli e Beuren (2002), a crença de que apenas "boas ideias" seriam suficientes para assegurar o sucesso e a sobrevivência de uma organização não vem 
Marcelo Nascimento - Carlos Rogério Montenegro de Lima - Mauricio Andrade de Lima- Eduardo Rolim Ensslin

demonstrando ser verdadeira por alguns motivos, entre eles estão as falhas nas previsões em que se apoiam os executivos e o fato de as mudanças ambientais serem tantas que os procedimentos estruturados se revelam insuficientes para adequar a organização à nova realidade.

Conforme pesquisa realizada pelo SEBRAE (2003), de cada dez empresas abertas, seis acabam fechando antes de cinco anos de vida. Até o primeiro ano de vida, $31 \%$ fecham suas portas. Esse número passa para $37 \%$ nos dois primeiros anos de vida e para $49 \%$ com três anos e 53\% com 4 anos de operação.

O Quadro 3, a seguir apresenta alguns estudos sobre as falências em PMEs de forma sintética, assim como seus respectivos anos e autores.

Quadro 3 - Estudos sobre falências das PMEs

\begin{tabular}{|c|c|c|}
\hline Autor & no & Abordagens dos estudos \\
\hline Yonemoto & 1998 & $\begin{array}{l}\text { Identificou os principais fatores externos e internos e a sua relação com o sucesso ou } \\
\text { fracasso das empresas de pequena dimensão }\end{array}$ \\
\hline Da Silva & 02 & Propôs uma série de medidas administrativas para evitar a morte prematura das MPEs \\
\hline Medina & 2002 & $\begin{array}{l}\text { Estudou as MPE's do setor do vestuário da grande Florianópolis. O grande objetivo desta } \\
\text { pesquisa se concentrou em descobrir quais os fatores que levam ao sucesso aquela mínima } \\
\text { percentagem de micro empresas que conseguem ultrapassar os três anos de existência. }\end{array}$ \\
\hline Pazolini & 2006 & $\begin{array}{l}\text { Foram investigados os fatores de sucesso intrínsecos dos micro e pequenos empresários e a } \\
\text { percepção do contador em um escritório de contabilidade, na região de Colatina, no estado } \\
\text { do Espírito Santo. }\end{array}$ \\
\hline Filardi & 2006 & $\begin{array}{l}\text { Identifica, descreve, classifica e analisa os fatores contribuintes para a mortalidade precoce } \\
\text { de micro e pequenas empresas de São Paulo. }\end{array}$ \\
\hline Nunes & 2006 & $\begin{array}{l}\text { Estuda e analisa a incubadora como instrumento fundamental para a continuidade de novos } \\
\text { empreendimentos }\end{array}$ \\
\hline Mai & 2006 & $\begin{array}{l}\text { Buscou identificar o perfil socioeconômico do empreendedor e os fatores que podem indicar } \\
\text { o sucesso ou o insucesso (mortalidade) das micro e pequenas empresas comerciais do } \\
\text { Município de Aracruz/ES. }\end{array}$ \\
\hline Ortigara & 2006 & $\begin{array}{l}\text { Realizou um workshop com profissionais e pesquisadores de MPEs sobre as causa } \\
\text { principais da falência. }\end{array}$ \\
\hline Ribeiro & 2006 & Estudou o que a MPE deve fazer para garantir sua continuidade. \\
\hline Nascimento & 2007 & $\begin{array}{l}\text { Identificou e analisou as causas de sucesso e insucesso das micro e pequenas empresas, } \\
\text { através de pesquisa de campo realizada na cidade de Floriano, estado do Piauí }\end{array}$ \\
\hline Ercolin & 2007 & $\begin{array}{l}\text { Buscou identificar, descrever, analisar e classificar os principais fatores financeiros } \\
\text { relacionados à morte prematura de micros e pequenas empresas na cidade de São Paulo }\end{array}$ \\
\hline Cardoso & 2007 & $\begin{array}{l}\text { verificou quais são as variáveis pertinentes aos empresários que impactam na continuidade } \\
\text { de suas micro e pequenas empresas, observadas em um escritório contábil na região de Vila } \\
\text { Velha no Estado do Espírito Santo. }\end{array}$ \\
\hline Da Silva & 2008 & $\begin{array}{l}\text { Buscou identificar e analisar as causas internas e externas que podem influenciar o sucesso } \\
\text { ou o fracasso das micro e pequenas empresas sediadas em Belo Horizonte, estado de Minas } \\
\text { Gerais }\end{array}$ \\
\hline Ribeiro Neto & 2008 & $\begin{array}{l}\text { Estudou alguns fatores que impactam o desempenho de MPE's a fim de evitar a falência das } \\
\text { mesmas. }\end{array}$ \\
\hline Cunha Junior & 2009 & $\begin{array}{l}\text { Analisou a situação de MPE's do Estado da Paraíba, identificando os principais fatores que } \\
\text { influenciam a vitalidade dessas unidades produtivas, seus arranjos institucionais e os } \\
\text { impactos de mudança institucionais sobre a mesma }\end{array}$ \\
\hline latos & 2009 & $\begin{array}{l}\text { o objetivo foi conhecer os principais pontos fortes dos empreendedores que já estão em } \\
\text { atividade há pelo menos três anos. }\end{array}$ \\
\hline
\end{tabular}

Fonte: Autores, (2013). 
Os trabalhos apresentados no Quadro 3 apresentam inúmeros fatores sobre a mortalidade de MPEs, os quais serão estudados na sequência deste artigo.

\subsection{FATORES CONTRIBUINTES PARA A MORTALIDADE}

Neste tópico, são identificados os principais fatores que contribuem para a falência das MPEs, classificando-os com a finalidade de explicar a alta taxa de mortalidade das empresas nos primeiros anos de atividade.

Na maioria das vezes, as pequenas e médias empresas têm apresentado certas dificuldades que, de acordo com Balestrin e Vargas (2003), envolvem obstáculos na obtenção de melhores preços e vantagens. Essas dificuldades são encontradas na compra de matérias-primas e componentes, nos custos de participação em feiras, nas campanhas publicitárias, na reciclagem e no treinamento da mão de obra, na atualização tecnológica, no acesso a linhas de crédito e financiamento, nos aluguéis e, finalmente, nos custos envolvidos na exportação de produtos.

Em sua pesquisa, Adizes (1990) cita como principais causas da mortalidade precoce os seguintes fatores: 1) sub-capitalização; 2) empréstimos de curto prazo para investimentos com retorno de longo prazo; 3) começar a vender com desconto para gerar dinheiro em caixa; 4) vender uma parte da empresa a capitalistas de risco com pouco compromisso com o negócio; 5) baixo compromisso do fundador; 6) intervenção governamental; 7) delegar funções importantes; 8) estagnação; 9) falta de foco; 10) ausência de sistemas administrativos; 11) falta de criatividade; e 12) falta de informação técnica.

Para Casarotto Filho e Pires (1998), o grande problema da pequena empresa é a falta de competência para dominar todas as etapas da cadeia de valor, além da própria falta de capacidade de gestão em todas as suas etapas.

Para efeito de classificação, com base nas causas identificadas na literatura sobre o assunto, Filardi e Santos (2008) dividem os fatores contribuintes para a mortalidade em três grandes blocos de variáveis, como demonstrado no Quadro 4. 
Quadro 4 - Classificação dos Fatores Contribuintes para a Mortalidade Precoce

\begin{tabular}{|c|c|c|}
\hline 1. O EMPREENDEDOR & 2. O NEGÓCIO & 3. O AMBIENTE EXTERNO \\
\hline $\begin{array}{l}\checkmark \quad \text { Competência na gestão } \\
\text { empresarial. } \\
\checkmark\end{array}$ & $\begin{array}{ll}\checkmark & \text { Acesso ao crédito. } \\
\checkmark & \text { Mão de obra }\end{array}$ & $\begin{array}{ll}\checkmark & \text { Burocracia legal e fiscal. } \\
\checkmark & \text { Competição dos }\end{array}$ \\
\hline$\checkmark \quad$ Nível de escolaridade. & $\checkmark \quad$ Planejamento & Demanda dos clientes. \\
\hline $\begin{array}{l}\checkmark \quad \text { Profissionalização da } \\
\text { relação com sócios. }\end{array}$ & $\begin{array}{l}\text { estratégico. } \\
\checkmark \quad \text { Suporte jurídico e } \\
\text { contábil. }\end{array}$ & $\begin{array}{l}\checkmark \quad \text { Fornecedores, } \\
\text { representantes, distribuidores e } \\
\text { parceiros. }\end{array}$ \\
\hline & $\begin{array}{l}\checkmark \quad \text { Qualidade de produtos } \\
\text { e serviços. }\end{array}$ & $\begin{array}{l}\checkmark \quad \text { Carga de impostos e } \\
\text { tributos. }\end{array}$ \\
\hline & $\begin{array}{l}\checkmark \quad \text { Inovação de produtos e } \\
\text { serviços. }\end{array}$ & $\begin{array}{l}\checkmark \quad \text { Aspectos econômicos, } \\
\text { políticos, tecnológicos, sociais e } \\
\text { ambientais. }\end{array}$ \\
\hline
\end{tabular}

Fonte: Filardi e Santos, (2008, p. 6).

Felippe (2003), com base em sua pesquisa, aponta quais são os motivos que mais levam as MPEs a serem insolventes, a saber: 1) falta de clientes $(32,1 \%) ; 2)$ falta de capital de giro $(21,4 \%) ; 3)$ carga tributária $(18,5 \%) ; 4)$ ponto inadequado $(17 \%) ; 5)$ recessão econômica (13\%); 6) maus pagadores (12,5\%); 6) falta de conhecimentos $(9,7 \%)$; 7) concorrência muito forte $(8,8 \%) ; 8)$ problemas financeiros $(7 \%) ; 9)$ falta de mão de obra $(5,4 \%) ; 10)$ falta de crédito $(3,5 \%)$; e 11$)$ outros motivos $(15,7 \%)$.

Em uma pesquisa do SEBRAE (2004), muitos fatores sobre a falência das MPEs foram acusados como sendo os principais. Desses fatores, alguns não podem ser administrados pelos gestores dessas organizações, como a falta de clientes, recessão econômica, carga tributária elevada etc. Porém, outros podem ser controlados pelos empreendedores, como falta de capital de giro, falta de conhecimentos gerenciais, local inadequado etc.

Os pesquisadores Birley e Niktari (1996) indicam outros fatores ligados ao perfil dos empreendedores, que contribuem diretamente para a mortalidade das pequenas empresas, que são: 1) possui perfil inflexível, resistente às mudanças e não aceita procurar ajuda externa; 2 ) contrata equipe de baixa competência e com baixa experiência no ramo; 3) apresenta falta de planejamento; e 4) possui falta de organização das operações da empresa.

Alguns resultados dessa mesma pesquisa revelam que $41 \%$ dos empresários entrevistados dizem ter acreditado exageradamente na intuição e emoção; 60\% 
confessaram que não planejaram o negócio; $23 \%$ disseram que fizeram retiradas acima do que o negócio poderia suportar; e 33\% não pediram auxílio ou consultoria externa.

Mai (2006) pesquisou sobre o perfil socioeconômico do empreendedor e os fatores que podem indicar o sucesso ou insucesso das micro e pequenas empresas. Os fatores de sucesso que se destacaram na pesquisa foram que o empresário que se enquadra na faixa etária, oscilando entre os 25 até 39 anos, e a classe social entre $A 1(R \$ 7.793,00)$ e B1 (R\$ 2.804,00) tem um perfil de sucesso. Além desses, pode-se citar a ausência dos seguintes fatores podem contribuir para o insucesso das empresas: 1) capital de giro; 2) capacidade de liderança do empresário; e 3) reinvestimentos dos lucros e planejamento.

Cleverly (2002) identifica 5 fatores que, de acordo com seus estudos, contribuem para a mortalidade de empresas, são eles: 1) um elevado nível de complacência com gastos na fase de abertura da empresa; 2) o nível de competência da diretoria e dos sócios varia muito, e muitos fazem parte da sociedade por causa do grau de parentesco, ou porque traz recursos financeiros, mas Ihes falta experiência empresarial; 3) em muitos casos, os novos empresários não têm recursos para abandonar seu atual emprego e se dedicar integralmente ao seu novo empreendimento; 4) muitos não conhecem o mercado onde estão entrando - são curiosos; e 5) muita informação e mudanças rápidas fazem com que os empresários não deem foco ao que é prioridade.

Os fatores que contribuem para a mortalidade precoce de empresas são diversos e as pesquisas já realizadas apontam em várias direções. Em resumo, podem ser listadas, entre outras, as seguintes variáveis que contribuem para o processo de mortalidade precoce das empresas: 1) falta de experiência do empreendedor; 2) baixo nível de escolaridade do empreendedor; 3) falta de habilidade na gestão empresarial do empreendedor; 4) falta de profissionalização na relação com os sócios; 5) falta de acesso ao crédito; 6) falta de mão de obra qualificada; 7) falta de planejamento estratégico; 8) falta de consultoria especializada (contábil e jurídica); 9) baixa qualidade do produto/serviço; 10) baixa inovação de produtos e serviços (diferenciação); 11) dificuldade de pagar os impostos e tributos; 12) Dificuldade em atender aos procedimentos legais, fiscais e tributários; 13) falta de competitividade em comparação com a concorrência no mercado; 14) dificuldade de atrair e manter clientes; 15) falta de profissionalização na relação com parceiros comerciais (fornecedores, 
representantes e distribuidores); e 16) problemas com o ambiente externo (econômico, político, tecnológico, socioambiental).

\section{PROCEDIMENTOS METODOLÓGICOS}

\subsection{CLASSIFICAÇÃO METODOLÓGICA}

Saunders, Lewis e Thornwill (2000) argumentam que existe a necessidade de se tratar do processo de pesquisa a partir de uma visão sistêmica, em que cada uma das etapas faz emergir uma questão e uma decisão sobre a linha metodológica que se pretende seguir. Para os autores, o processo segue as seguintes "camadas": filosofia da pesquisa, lógica da pesquisa, abordagem do problema, objetivos da pesquisa, estratégia da pesquisa, horizonte de tempo e método de coleta de dados.

Esse estudo terá uma filosofia da pesquisa com enfoque positivista, pois segundo Collis e Hussey (2005, p. 58), a pesquisa ora proposta procura os fatos ou causas de fenômenos sociais, dando pouca importância ao estado subjetivo do indivíduo. Portanto, o raciocínio lógico é aplicado à pesquisa de modo que precisão, objetividade e rigor substituam palpites, experiências e intuição como maneira de investigar problemas de pesquisa.

A lógica desta pesquisa, portanto, será indutiva, pois será feito um estudo sobre quais são os motivos que, sob o ponto de vista dos contadores, conduzem as MPEs à insolvência, criando, assim, um postulado e não partindo de uma lei.

No que tange à abordagem do problema, esta pesquisa pretende descrever e analisar fatos e fenômenos da realidade com enfoque quantitativo, pois a análise realizada procura identificar e caracterizar fatores que levam uma MPE à falência e utiliza meios estatísticos para tabular os dados e informar os resultados. Por meio das técnicas quantitativas, é possível embasar as informações qualitativas com o apoio de métodos estatísticos (RICHARDSON, 1999).

Os objetivos da pesquisa foram desenvolvidos por meio de uma pesquisa explicativa. De acordo com Gil (1991), o estudo explicativo visa a identificar os fatores que 
determinam ou contribuem para a ocorrência dos fenômenos. Aprofunda o conhecimento da realidade porque explica a razão, o "porquê" das coisas. Quando realizada nas ciências sociais, requer o uso do método observacional. Assume, em geral, as formas de Pesquisa Experimental e Pesquisa Expost-facto. Segundo Kerlinger (1980), um estudo é não experimental, ou expost-facto, quando não há manipulação de dados, isto é, tentativa deliberada e controlada de produzir efeitos. As relações entre os fenômenos são estudadas após a ocorrência dos mesmos e sem qualquer intervenção. As características do objeto de análise são, dessa forma, identificadas e as relações entre as mesmas são observadas, mas não há qualquer tentativa de mudança.

Do ponto de vista da estratégia, esta pesquisa será de caráter bibliográfico e por levantamento. A pesquisa bibliográfica, segundo Gil (1991),

explica um problema a partir de referenciais teóricos publicados em documentos. Pode ser realizada independentemente ou como parte da pesquisa descritiva ou experimental. É uma pesquisa por levantamento, pois será aplicado um questionário para interrogação das pessoas que trabalham diretamente com os empresários das MPEs que faliram - nesse caso, os contadores. Ambos os casos buscam conhecer e analisar as contribuições culturais ou científicas do passado existentes sobre um determinado assunto, tema e problema.

Quanto ao horizonte do tempo, esta pesquisa é classificada como transversal, uma vez que os dados são coletados apenas uma vez, em período de tempo curto, antes de serem analisados e relatados. É, assim, um instantâneo de uma situação em andamento.

\subsection{PROCEDIMENTOS DE COLETA E ANÁLISE DE DADOS}

Para proceder à coleta e análise de dados, foi adotada uma estratégia baseada na aplicação de um questionário semi-estruturado junto com todos os escritórios de contabilidade da região metropolitana de Florianópolis, conhecendo, assim, quais são os fatores que levam uma empresa à falência. Para isso, o presente projeto obteve acesso aos dados de todos os escritórios contábeis de Florianópolis junto ao Conselho Regional de Santa Catarina (CRC), pois esse órgão é responsável pelo registro dos mesmos. O mesmo órgão enviou o questionário para os escritórios contábeis via correio eletrônico institucional. 
Assim, foram encontrados 359 Organizações Contábeis Individuais e 437 Organizações Contábeis de Sociedades, em um total de 796 (População) escritórios até fevereiro de 2011. Dessa população, foi coletada uma amostra de 141 com erro amostral de 0,076.

As ferramentas para se chegar aos objetivos foram a análise documental, ou seja, foram analisados os dados referentes às empresas falidas no período de 2007 a 2011.

A análise dos dados foi feita de forma descritiva por meio de análise e descrição de gráficos e tabelas obtidas com a tabulação das respostas dos questionários com a utilização do software Statistical Package for the Social Sciences (SPSS) e tabulações feitas no Microsoft Excel.

Para compreender melhor quais são os fatores que levam à falência as MPEs sob a ótica do contador, foram estabelecidos alguns critérios: 1) a experiência do empresário; 2) o nível de escolaridade; 3) a idade média antes de a empresa falir; 4) a utilização de informações contábeis como ferramentas gerenciais; 5) os planejamentos estratégicos e tributários; 6) a dificuldade no recolhimento dos impostos e tributos; e 7) a manutenção de mão de obra qualificada.

Para se chegar a esses fatores, foi feito um levantamento sobre quais fatores mais apareceram nos trabalhos citados na fundamentação teórica. Com esse levantamento, obteve-se a Tabela 1.

Tabela 1 - Ordem de classificação dos fatores citados pelos autores que levam as MPEs à falência

\begin{tabular}{l|l|l}
\hline Ordem & Fatores & $\begin{array}{l}\text { Quantidade } \\
\text { de autores }\end{array}$ \\
\hline 1 & Falta de capital de Giro & 18 \\
\hline 2 & Falta de capacitação (escolaridade) & 17 \\
\hline 3 & Incompetência gerencial e má gestão & 17 \\
\hline 4 & Falta de planejamento estratégico & 15 \\
\hline 5 & Falta de conhecimento do mercado & 12 \\
\hline 6 & $\begin{array}{l}\text { dão existência de política de preços, produtos, propaganda e } \\
\text { distribuição }\end{array}$ & 12 \\
\hline 8 & Carga tributária elevada & 10 \\
\hline 9 & Falta de mão de obra qualificada & 8 \\
\hline 10 & Acesso ao crédito & 8 \\
\hline & Falta de plano de negócios & 7 \\
\hline
\end{tabular}

Fonte: Elaborada pelos autores, 2013. 
Dessa forma, pretendeu-se também identificar se os motivos que levam as MPEs da Grande Florianópolis à falência, sob a ótica do contador, possuem características em comum aos motivos citados em outros estudos pelos empresários.

\subsection{HIPÓTESES INVESTIGADAS}

Todas as hipóteses abaixo estão relacionadas com os fatores sob a ótica do contador que estão levando as MPEs a falir.

$\checkmark$ H1: quanto menos Capital de Giro a empresa possui, maior a chance de falência;

$\checkmark$ H2: quanto menor o nível de escolaridade do(s) empreendedor(es) ou sócio(s), maior a chance de mortalidade;

H3: quanto maior a falta de competência gerencial, maior a chance de falência de uma MPE;

$\checkmark$ H4: as MPEs que não têm planejamento possuem maior propensão à falência;

H5: quanto menor a falta de conhecimento do mercado, maior a chance de falência das MPEs.

$\checkmark$ H6: as MPEs que não possuem a existência de política de preços, produtos, propaganda e distribuição, tendem a uma maior chance de falência;

$\checkmark$ H7: quanto maior a carga tributária, maior a chance de mortalidade;

H8: quanto maior a manutenção de mão de obra qualificada, menor a chance de mortalidade das MPEs;

$\checkmark$ H9: quanto menor for o acesso ao crédito, maior a chance de falência;

$\checkmark$ H10: as MPEs que não possuem Plano de Negócios possuem maior propensão à falência.

\section{APRESENTAÇÃO E ANÁLISE DOS DADOS}

Neste item, estão expostas as informações obtidas a partir da análise dos dados de acordo com cada uma das circunstâncias investigadas na presente pesquisa. $\mathrm{Na}$ análise R. eletr. estrat. neg., Florianópolis, v.6, n.2, p. 244-283, mai./ago. 2013 
descritiva, as respostas do questionário foram distribuídas em três categorias distintas: caracterização do empreendedor, caracterização da empresa e caracterização do ambiente externo.

Pela análise do Gráfico 1, percebe-se que a maioria dos escritórios contábeis, cerca de $50 \%$, tem em suas carteiras de clientes até 40 empresas.

Gráfico 1 - Número de empresas clientes dos escritórios

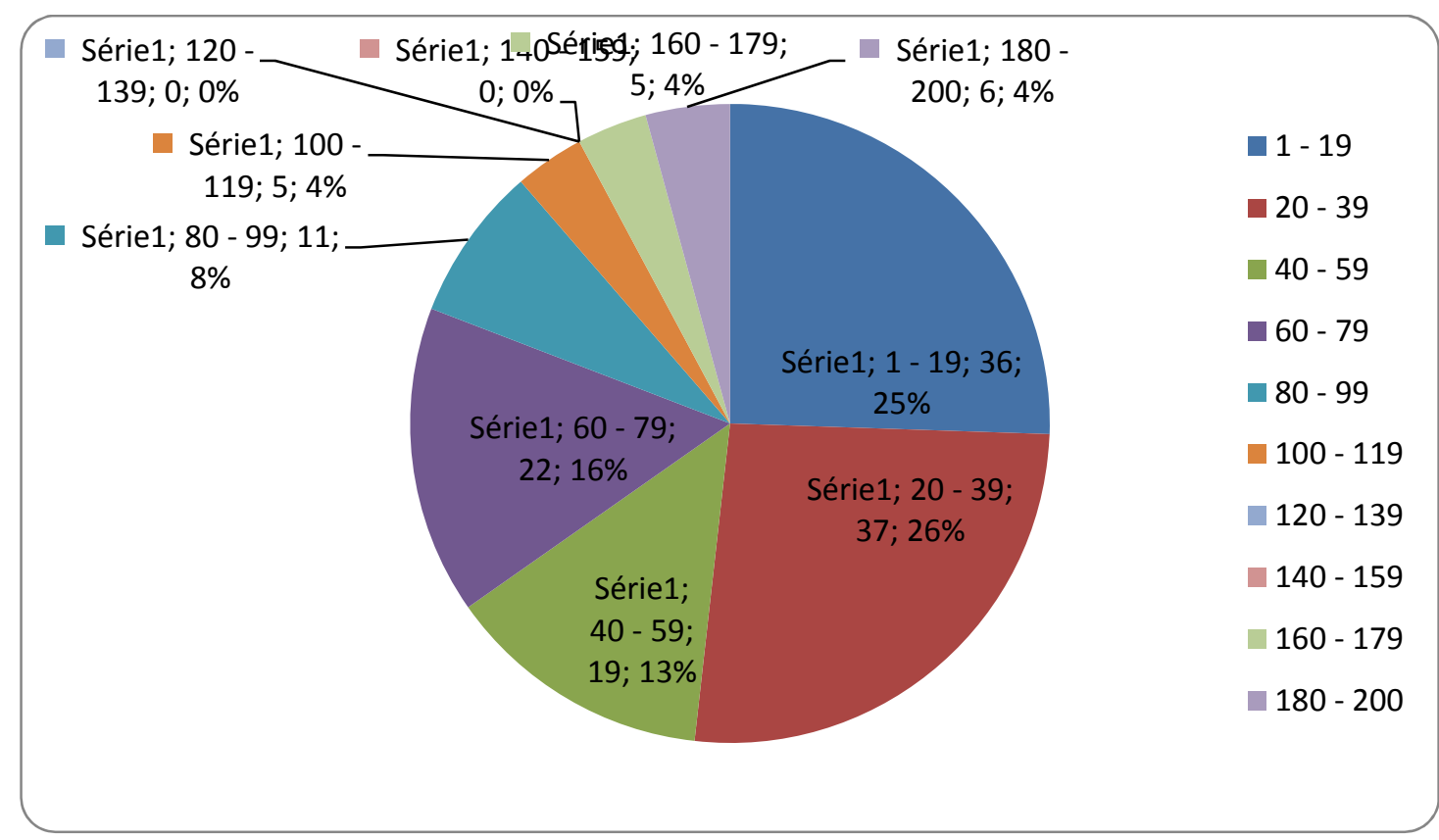

Fonte: Dados da Pesquisa, 2013.

Analisando a Gráfico 2, chega-se à conclusão de que os escritórios contábeis possuem mais clientes do setor de serviços, acompanhado de comércio e indústria. Tal fato corrobora com a pesquisa de De Geus (1998), onde o autor comenta que nas MPEs o setor de maior expansão nos últimos anos é o de serviços, que tem apresentado um crescimento maior do que indústria e comércio. $\mathrm{O}$ autor conclui que atualmente existe uma maior atenção às empresas prestadoras de serviços na economia, que outrora era dominada pela atividade industrial. 
Gráfico 2 - Percentual de empresas clientes do escritório por setor



Fonte: Dados da Pesquisa, 2013.

22\% dos escritórios contábeis, ao serem indagados sobre a quantidade de empresas clientes que faliram nos últimos cinco anos, apontaram apenas uma MPE; $13 \%$ apontaram duas MPEs como número de falências e 11\% apontaram três MPEs que faliram nos últimos cinco anos. Uma porcentagem que chamou a atenção foi que $28 \%$ dos escritórios contábeis têm um número igual ou superior a sete clientes de micro e pequeno porte que faliram nos cinco anos anteriores à pesquisa, conforme mostra a Gráfico 3.

Gráfico 3-Quantidade de empresas clientes que faliram nos últimos cinco anos



Fonte: Dados da Pesquisa, 2013. 
Ao analisar a Gráfico 4, observa-se que 37\% dos empreendedores tinham experiência no ramo de atividade de sua empresa - entre um e cinco anos. Na mesma proporção de $37 \%$, os empresários que abriram uma empresa não possuíam experiência alguma sobre o ramo que estava ingressando. Em contrapartida, apenas $4 \%$ das MPEs que faliram possuíam sócios com experiência acima da 5 anos.

Assim, de acordo com o Gráfico 4, no mínimo $88 \%$ das empresas que faliram se enquadram em um fator de risco das MPEs, conforme literatura observada, isto é, quanto menor a falta de conhecimento do mercado, maior a chance de falência das MPEs.

De acordo com os dados do Gráfico 4, pode-se concluir que a quinta hipótese é válida, pois $52 \%$ das empresas, no mínimo, possuem um tempo menor que um ano de experiência na atividade semelhante. Assim, quanto menor a falta de conhecimento do empreendedor no mercado entrante, maior a chance de falência.

Gráfico 4 - Tempo de experiência do empreendedor no ramo da atividade semelhante à que abriu a empresa

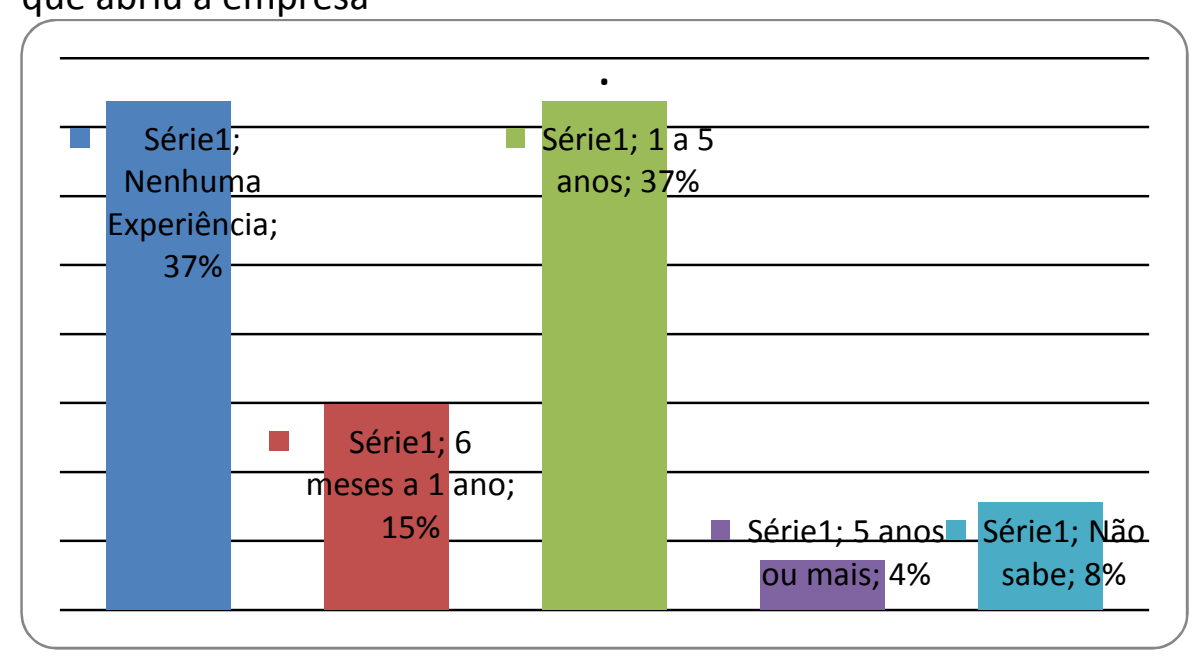

Fonte: Dados da Pesquisa, 2013.

Quanto ao nível de escolaridade do empreendedor, a Gráfico 5 aponta um nível de escolaridade acima da média em Santa Catarina, visto que 78\% possuem no mínimo o segundo grau. Como base para o nível de escolaridade, essa pesquisa utilizou a Tabela de Indicadores de Desenvolvimento Humano (2010), que aponta uma média de anos de escolaridade de 7,2. Já Santa Catarina aparece com 8,03\%, ou seja, um número inferior ao 20 grau. 
Gráfico 5 - Nível de escolaridade do empreendedor

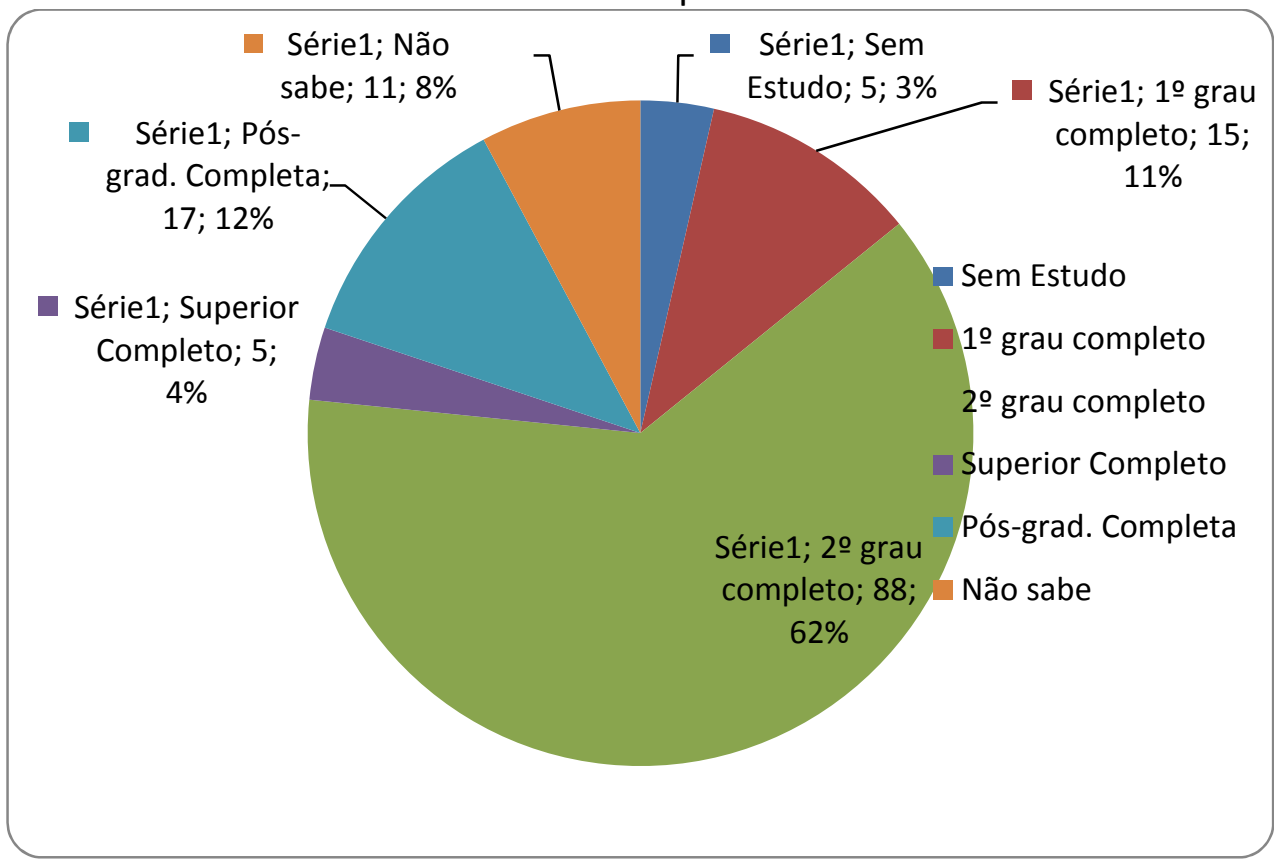

Fonte: Dados da Pesquisa, 2013.

Na maioria (62\%) das empresas que faliram, os sócios possuíam o 2ํgrau completo. Com $12 \%$ e $4 \%$, os empreendedores possuíam, respectivamente, o superior completo e a pós-graduação. Com o 1 으 grau completo, enquadram-se nos $11 \%$ dos empreendedores que faliram. E apenas 3\% dos empreendedores não possuíam estudo algum, demonstrando grau de instrução abaixo daqueles que não obtiveram sucesso em suas empreitadas.

Buscando verificar se quanto menor o nível de escolaridade do(s) empreendedor(es) ou sócio(s), maior a chance de mortalidade, a segunda hipótese busca responder se as empresas falidas possuíam sócios com nível de escolaridade baixo.

Conforme analisado no Gráfico 5, apenas 3\% dos sócios das MPEs que faliram não possuíam estudo, dessa forma, refutando a segunda hipótese que afirma que o baixo nível de escolaridade do empreendedor tende a uma maior chance de falência.

Apesar de $86 \%$ dos empreendedores possuírem no mínimo o 2o grau, e no mínimo 56\% possuírem alguma experiência na área de empreendimento, conforme se pode analisar no Gráfico 6, no mínimo, 65\% deles não possuíam experiência em termos de gerência anterior ao iniciarem suas empresas. Por outro lado, somente $11 \%$ possuíam experiência em nível de gerência ou diretoria na área antes de abrir o negócio. 
Gráfico 6 - Trabalhou em nível de gerência antes de abrir o negócio

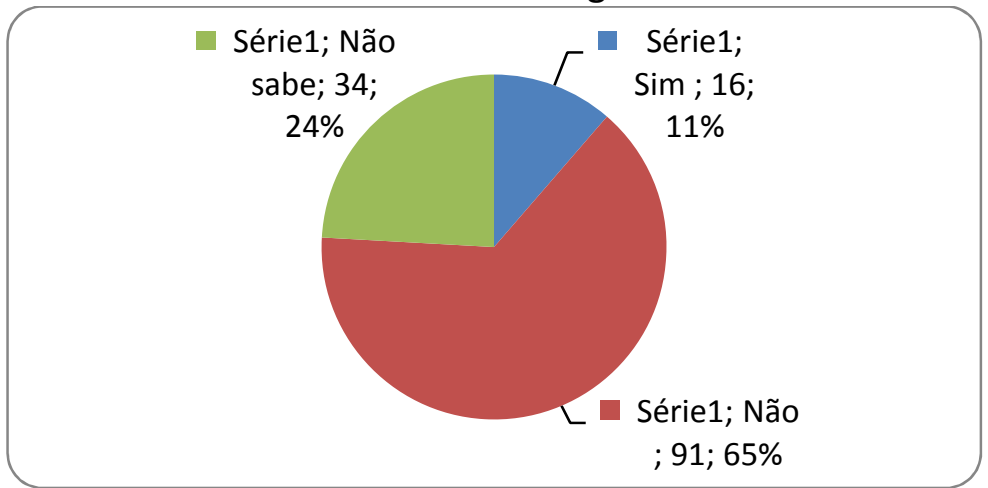

Fonte: Dados da Pesquisa, 2013.

O contador, quando indagado sobre se o empreendedor ou sócio, sob o seu ponto de vista, gerenciava de maneira competente o seu negócio, respondeu em sua grande maioria que "não", demonstrando, assim, que o fator escolaridade não foi primordial para um gerenciamento competente da organização. Apenas $12 \%$ afirmaram que os sócios gerenciavam de maneira competente suas empresas e $8 \%$ não souberam informar (Gráfico 7).

Gráfico 7 - O empreendedor gerenciava de maneira competente o seu negócio

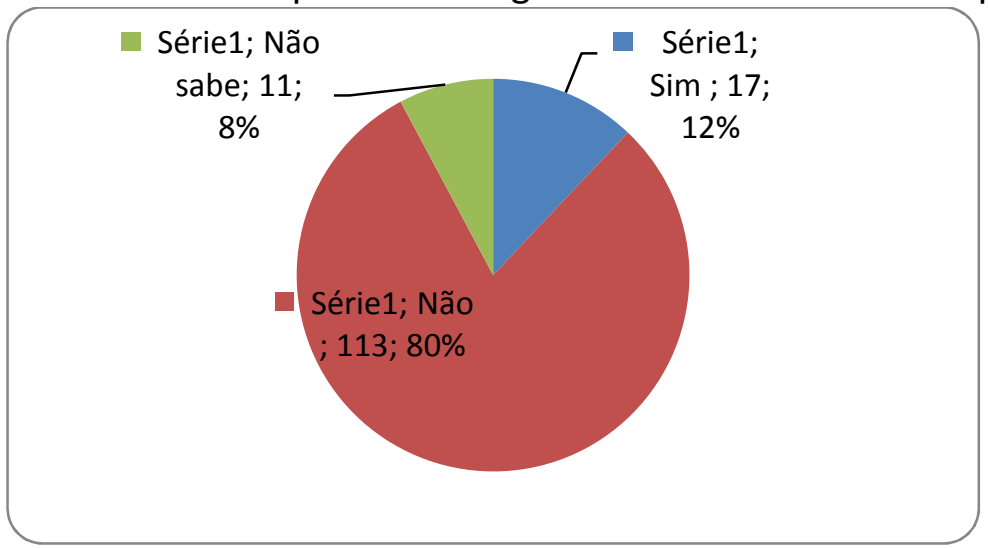

Fonte: Dados da Pesquisa, 2013.

Conforme o gráfico 8,76\% dos empreendedores não realizaram nenhum curso de empreendedorismo antes de constituírem suas empresas. Por outro lado, somente $8 \%$ realizaram algum tipo de curso. Esse questionamento vai ao encontro do Gráfico 7, onde $80 \%$ dos contadores não consideram que os empreendedores gerenciam suas empresas de maneira competente, fator que pode ser explicado pela falta de cursos de empreendedorismo. 
$\mathrm{Na}$ terceira hipótese da pesquisa, afirmou-se que quanto maior a falta de competência gerencial, maior a chance de falência de uma MPE. Sendo assim, indagou-se ao contador se, sob sua ótica, o empresário possuía essa competência. Para reforçar a avaliação sobre competência gerencial, foi inserida no questionário uma pergunta para saber se o empresário já havia realizado algum curso de empreendedorismo antes de abrir a empresa.

Conforme apresentado, 80\% dos empreendedores da MPEs não gerenciavam de maneira competente os seus negócios e $76 \%$ nunca realizaram nenhum curso de empreendedorismo. Dessa forma, os dados apresentados permitem aceitar a terceira hipótese, que afirma que quanto maior a falta de competência gerencial, maior a chance de falência de uma MPE.

Gráfico 8-O empresário fez algum curso de empreendedorismo antes de abrir a empresa

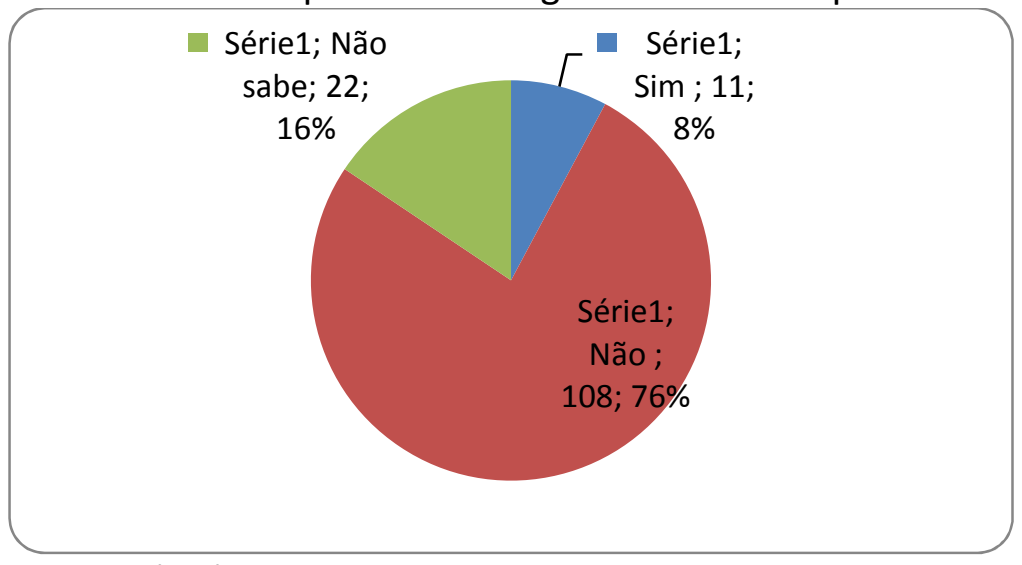

Fonte: Dados da Pesquisa, 2013.

Ao analisar o Gráfico 9, chega-se à conclusão que 79\% das MPEs que faliram tinham idade menor que dois anos e $16 \%$ entre três e cinco anos de vida. Apenas $4 \%$ possuíam idade superior a cinco anos. Tal resultado segue a tendência do SEBRAE (2008), que mostrou que, antes de 2005, a metade dos empreendimentos fechava suas portas antes de completar dois anos. 
Gráfico 9 - Idade antes de sucumbirem (falirem)

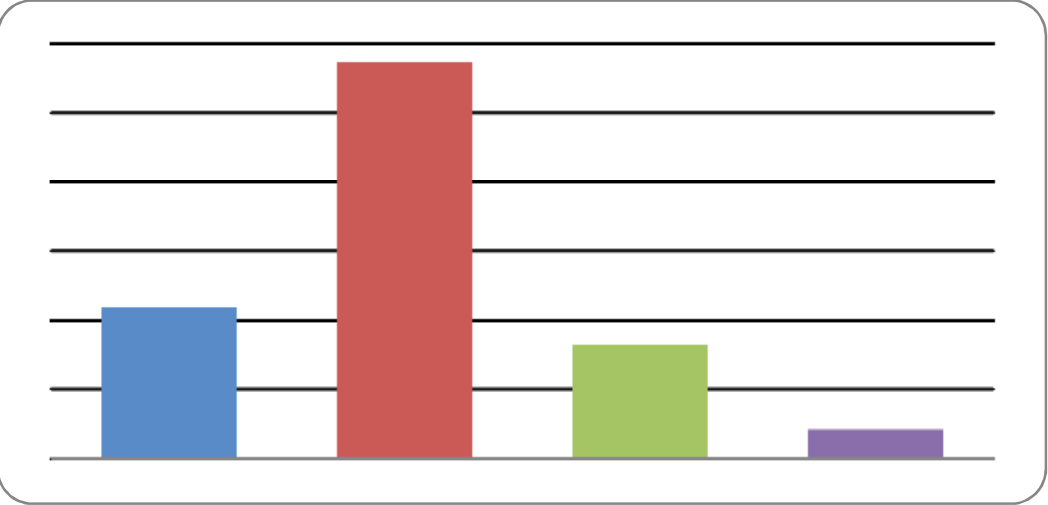

Fonte: Dados da Pesquisa, 2013.

Das empresas que entraram em falência, os setores de comércio e serviço formam $88 \%$ do total de falências, fato explicado pelo total de empresas clientes, que, na sua maioria, representam esses dois setores. Indústria e serviço, por sua vez, representam $8 \%$ e somente indústria representa apenas $4 \%$ do total de empresas falidas (Gráfico 10).

Gráfico 10 - Falência por setor - Setor da empresa que mais faliram

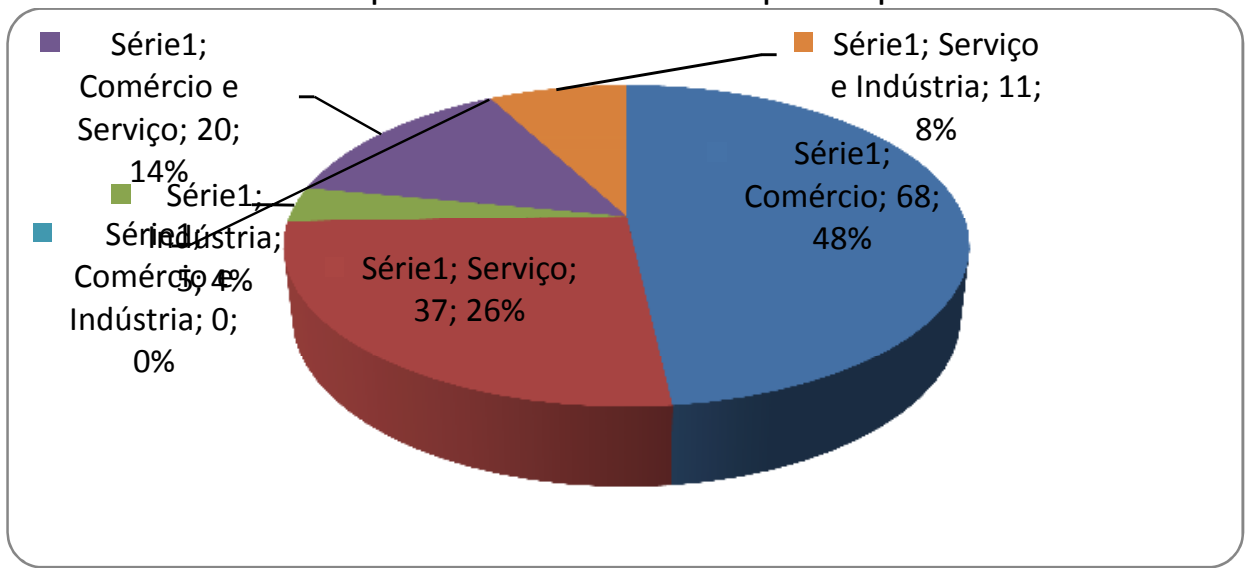

Fonte: Dados da Pesquisa, 2013

$\mathrm{Na}$ questão relativa ao número de funcionários, $77 \%$ das empresas apresentavam até nove funcionários, contra $15 \%$ que apresentavam entre 10 e 20 , e $8 \%$ apresentavam 20 ou mais funcionários. Como se percebe, a falência dessas MPEs gera muitos casos de desemprego, corroborando com a pesquisa do SEBRAE (2004), que aponta que no período de 2000 a 2002, com o fechamento de 770 mil empresas, foi ocasionada a perda de 2,4 milhões de postos de trabalho, contribuindo para o crescimento das taxas de 
desemprego, as quais demonstram um desperdício de $\mathrm{R} \$ 19,8$ bilhões decorrente do fim das atividades empresariais.

Quando indagado ao contador se a empresas dispunham dos recursos financeiros necessários para financiar o capital de giro, seja por meio de bancos, agências de fomento, capital de terceiros ou capital próprio, conforme Gráfico 14, apenas 34\% tinham recursos necessários para a manutenção da entidade, porém mais da metade, 54\%, não possuíam o capital de giro necessário para arcar com suas exigências a curto prazo. Em $12 \%$ das respostas, o contador não soube responder a essa questão.

Buscando verificar se quanto menos Capital de Giro a empresa possui, maior a chance de falência, a primeira hipótese busca responder se as empresas falidas possuíam tal recurso financeiro.

Dessa forma, é possível provar com 54\% que as MPEs que não possuem o capital de giro adequado para serem autossustentáveis nos primeiros anos de vida são mais suscetíveis à falência. Assim, essa hipótese se confirma demonstrando que o senso comum, que afirma que as MPEs sem capital de giro não sobrevivem, está correto.

Conforme a pesquisa de Yonemoto (1998), SEBRAE (1999), Balestrin e Vargas (2003), Felippe (2003), SEBRAE (2004), Ribeiro Neto (2008) e Filardi e Santos (2008), um dos motivos que levam o empresário a não buscar recursos financeiros de terceiros são os juros altos, as dificuldades de dar garantias e comprovação de renda e a burocracia das instituições financeiras.

Das empresas que não dispunham de capital de giro, conforme mostra Gráfico 11, 47\% tinham dificuldades em conseguir crédito com bancos e agências de fomento por falta de garantias. O segundo fator mais acusado pelos contadores e que gerou a dificuldade de conseguir o empréstimo foi os juros altos, com $21 \%$. $13 \%$ citaram as regras para empréstimo, $8 \%$ outros fatores e $11 \%$ não souberam informar.

Conforme a nona hipótese deste estudo, que afirma que quanto menor for o acesso ao crédito, maior a chance de falência, esta pesquisa irá demonstrar se essa afirmativa é válida ou não.

Dos 76 empresas que não dispunham de capital próprio (54\%), conforme mostra o Gráfico 12, 89\% delas possuíam alguma dificuldade para conseguir um empréstimo. Dessa 
forma, validando a nona hipótese, que afirma que quanto menor for o acesso ao crédito, maior a chance de falência de uma MPE.

Gráfico 11 - Dificuldades para conseguir empréstimos

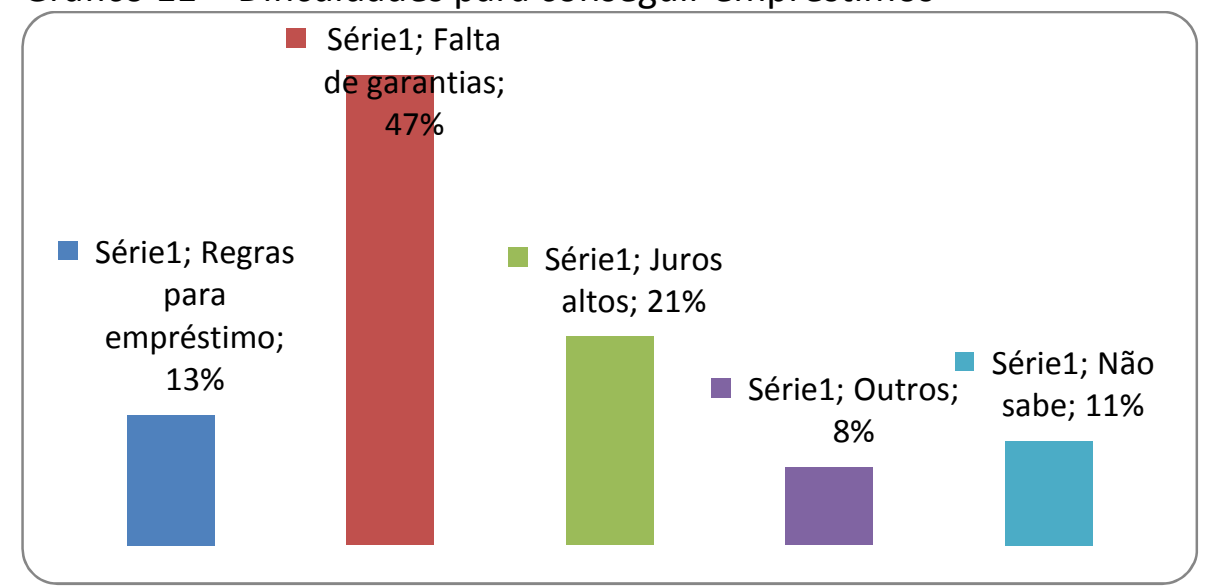

Fonte: Dados da Pesquisa, 2013.

Conforme analisado no Gráfico $12,66 \%$ das MPEs que faliram contratavam profissionais com menos de 1 ano de experiência, fato esse que pode ser explicado por possuírem pouca experiência e não exigirem salários altos. Esse fator se torna relevante ao levar em conta que apenas $20 \%$ contratavam profissionais com mais de um ano de experiência. Esses profissionais com mais experiências, que agregam valor à organização, são escassos nas empresas que faliram.

Gráfico 12 - Experiência dos profissionais contratados



Fonte: Dados da Pesquisa, 2013. 
Buscando responder a oitava hipótese deste trabalho, que afirma que quanto maior a manutenção de mão de obra qualificada, menor a chance de mortalidade das MPEs, será analisado o Gráfico 12. A mesma aponta que na sua grande maioria, $66 \%$ dos entrevistados possuíam em seus clientes de MPEs falidas profissionais com pouca qualificação, ou seja, experiência menor que 1 ano.

Com fulcro do exposto, pode-se validar a oitava hipótese, pois esses dados indicam como tendência as empresas que contam com funcionários com maior tempo de experiência sobreviverem mais tempo, visto que a dificuldade na manutenção de mão de obra qualificada pode ser considerada um fator contribuinte para a mortalidade precoce das empresas estudadas.

Em relação à pergunta "a empresa teve assessoramento com relação aos aspectos jurídicos e contábeis com o objetivo de otimizar a administração da empresa?", as respostas demonstram que $60 \%$ dos contadores deram suporte aos empreendedores antes de abrirem suas empresas e $40 \%$ não tiveram nenhum assessoramento.

Fischmann e Almeida (2009) apontam que o planejamento estratégico é uma técnica administrativa que cria a consciência das suas oportunidades e ameaças, dos seus pontos fortes e fracos para cumprir a sua missão, o qual é feito por meio de uma análise no ambiente da organização. Das empresas falidas, no mínimo $81 \%$ não possuíam planejamento, ou seja, não conheciam seus pontos fracos nem os seus pontos fortes, ficando à mercê do acaso. Somente $11 \%$ tinham planejamento estratégico conforme o Gráfico 13.

\section{Gráfico 13 - Planejamento estratégico}

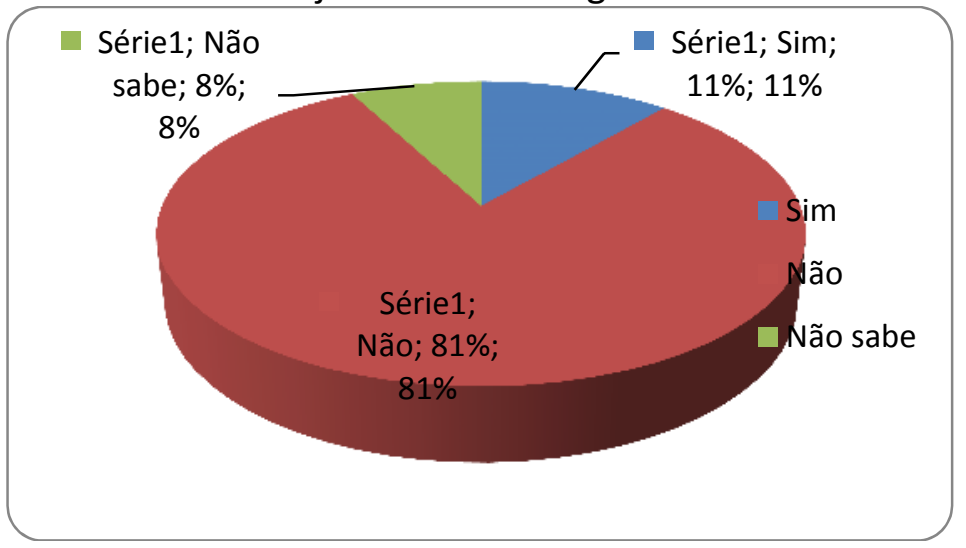

Fonte: Dados da Pesquisa, 2013.

R. eletr. estrat. neg., Florianópolis, v.6, n.2, p. 244-283, mai./ago. 2013 
Filardi (2006) indica quais são os principais motivos declarados pelos empresários para não realizar planejamento: 1) confia mais na experiência e na prática; 2) o contador fazia tudo, por isso não havia necessidade de planejar e nem de acompanhar nada; 3) foi atrás de uma oportunidade; 4) não se importa com isso, não acredita muito em planejamento; 5) acredita mais na fé, na raça e na coragem; 6) acredita mais na intuição; e 6) agiu por impulso e não teve tempo de planejar.

Para efeito desta pesquisa, utilizou-se para a quarta hipótese a seguinte assertiva: as MPEs que não têm planejamento possuem maior propensão a falência.

Como analisado no Gráfico 13 , pode-se verificar que apenas $11 \%$ afirmaram possuir planejamento estratégico antes de abrir a empresa e a que grande maioria, ou seja, $81 \%$ afirmaram que não realizaram nenhum tipo de planejamento antes de abrirem seus empreendimentos.

Com base nos dados citados, identificou-se que as empresas que não possuem planejamento estratégico tendem a uma maior chance de falência. Sendo assim, a quarta hipótese é válida.

Analisando-se o Gráfico 14, chega-se à conclusão de que a grande maioria das MPEs não utilizam informações contábeis como ferramenta gerencial, chegando a $81 \%$. Por outro lado, apenas $8 \%$ se utilizam desses demonstrativos contábeis para se basear suas decisões gerenciais. 
Gráfico 14 - Informações contábeis como ferramenta gerencial



Fonte: Dados da Pesquisa, 2013.

De acordo com o SEBRAE (2008), quem faz um bom Plano de Negócios, conhece o mercado e seu cliente, e quem dispõe de capital de giro, tem mais chances de dar certo. Conforme as respostas, 77\% das MPEs que faliram não escreveram um plano de negócios, desconhecendo, assim, vários fatores que dariam grande suporte para gerenciamento e com isso evitariam a falência dessas organizações. Somente $23 \%$ dessas MPEs escreveram um Plano de Negócios antes de iniciarem suas atividades.

Em relação à décima hipótese, que afirma que as MPEs que não possuem Plano de Negócios, possuem maior falência, este estudo irá aceitá-la ou refutá-la.

A pesquisa também apontou que $77 \%$ das MPEs que faliram não realizaram um Plano de Negócios, o que leva a aceitar a décima hipótese.

Das empresas que escreveram o Plano de Negócios, 47\% contaram com a ajuda do contador e $53 \%$ fizeram sem a ajuda do mesmo. Esse fato alerta para a pouca procura de um profissional qualificado no momento de abertura de uma empresa.

Conforme questionamento sobre o cálculo de capital de giro, apenas 26 (18\%) empresas calcularam o capital de giro necessário para o início de suas atividades, porém, 99 empresas (mais de 70\%) não calcularam o capital mínimo para que fossem financeiramente sustentáveis.

Quando perguntado aos contadores se a empresa mantinha a existência de política de preços, produtos, propaganda e distribuição, $62 \%$ disseram que não mantinham 
tal existência e apenas 15\% tinham tal política. Dos respondentes, 23\% não sabiam, conforme mostra o Gráfico 15.

Buscando verificar se as MPEs que não possuem uma política de preços, produtos, propaganda e distribuição tendem a uma maior chance de falência, a sexta hipótese busca responder se as empresas falidas possuíam tal política.

Na análise do Gráfico 15, pode-se concluir que 62\% não possuem tal política. Assim, a sexta hipótese torna-se válida para esta pesquisa.

Sob o ponto de vista do contador, $66 \%$ dos respondentes afirmaram que as MPEs que faliram não possuíam alta carga tributária e 33\% alegaram que as MPEs falidas sofriam com a alta carga tributária.

A sétima hipótese investigada tem o intuito de analisar se quanto maior a carga tributária, maior a chance de mortalidade.

Os resultados demonstram que, sob a ótica dos contadores, $66 \%$ das micro e pequenas empresas não possuíam alta carga tributária, e, portanto, a sétima hipótese foi refutada, já que o fator alta carga tributária não foi relevante para a mortalidade das MPEs.

Gráfico 15 - Existência de política de preços, produtos, propaganda e distribuição

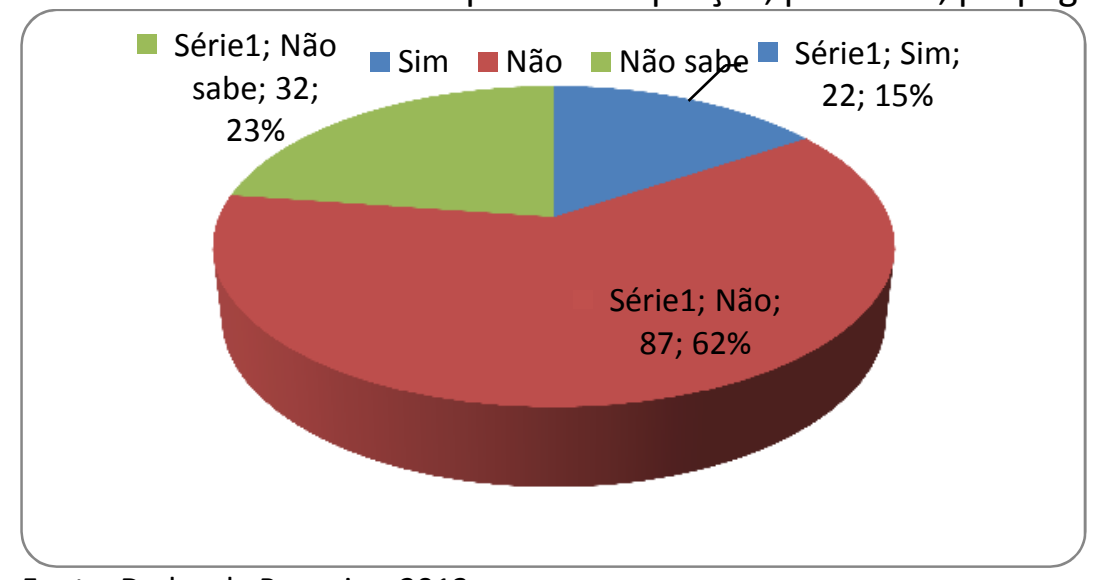

Fonte: Dados da Pesquisa, 2013.

Dos 48 respondentes que afirmaram que a as MPEs sofriam com a alta carga tributária, 52\% acham que um dos fatores determinantes de falência foi esse motivo e $48 \%$, embora achem que as MPEs tinham alta carga tributária, não atribuem esse fator como determinante da falência das mesmas. 
Com base nos dados extraídos da presente pesquisa, revela-se claramente que a vocação para o empreendedorismo no Brasil se mostra muito mais quantitativo do que qualitativo, visto que um grande número de novas empresas é criado todos os anos, mas a maioria não se sustenta e tem a sobrevivência comprometida principalmente pela origem da motivação do empreendedor, voltada mais para a sua necessidade pessoal do que para a identificação de uma oportunidade de negócio.

\section{RECOMENDAÇÕES}

Esta pesquisa buscou contribuir para a discussão dos fatores que levam as micro e pequenas empresas da região metropolitana de Florianópolis ao insucesso, analisando os principais aspectos sob a ótica dos contadores e buscando formas para reduzir os índices de mortalidade das novas empresas no Brasil, sem, contudo, ter a pretensão de esgotar o assunto.

No decorrer da pesquisa, cada contador que respondeu o questionário teve a oportunidade de dar sugestões e conselhos para tornar mais fácil o processo de criação e gestão de um empreendimento para outras pessoas que, eventualmente, venham a ter interesse em constituir empresas de micro ou pequeno porte.

Essas proposições serão apresentadas a seguir, em forma de recomendações, com o objetivo de eliminar ou reduzir os fatores que causam a morte precoce de empresas sob a ótica dos contadores, buscando dar subsídios para que as empresas dos futuros empreendedores possam ter um destino melhor do que as analisadas neste estudo, gerando mais emprego e renda para todos os envolvidos e dinamizando a economia brasileira.

A primeira recomendação é que o candidato a empreendedor deve ter certeza se é isso mesmo o que ele quer para sua vida, se ele realmente quer se tornar um empresário, pois terá que trabalhar muitas vezes mais do que trabalhava em seus empregos anteriores, sofrerá com maiores responsabilidades e pressões, enfim, terá de gostar do que faz. Não se recomenda também fundar a empresa apenas por motivos de desemprego e aposentadoria, visto que o empreendedor deve ter vocação naquela atividade. 
O empresário deve, para ter sucesso, fazer uma pesquisa de mercado, não se guiar somente por conselhos de amigos e parentes, averiguar se o ramo está carente ou sobrecarregado na região e ter muita ousadia na implantação do negócio, ou seja, ter capacidade técnica e financeira para investimentos a longo prazo. Essa pesquisa de mercado pode vir após um bom Plano de Negócios, onde o mesmo analisará se é viável e então começar as tomadas de decisões. Na prática, o que acontece é que os empreendedores procuram o contador quando já estão com a empresa funcionando, somente para fins de legalização do negócio.

Os contadores entrevistados nesta pesquisa desaconselham a abertura de uma empresa apenas para emitir Notas Fiscais, ou seja, por exigência de um empregador, pois essa prática foge da lei trabalhista que rege as relações de trabalho no Brasil e pode acarretar problemas futuros.

Fazer um bom planejamento estratégico também é fundamental para o bom andamento das MPEs sob a ótica dos contadores. Se possível, recomenda-se que o empresário busque alternativas nas incubadoras de empresas, pois os resultados de sobrevivência das empresas dentro desse regime vêm sendo positivo, reduzindo as taxas de mortalidade das organizações que passam pelos processos de incubação.

É aconselhável que sempre haja uma separação da vida pessoal e econômica do sócio da vida da empresa, principalmente quando se trata da parte financeira.

Outro fator relevante para abrir um negócio é ter o capital inicial sem expectativa de lucros no primeiro ano. É necessário, dessa forma, confrontar o montante disponível com o montante necessário para o início saudável da empresa. Se não for possível o montante do capital total, deve-se buscar outros caminhos para garantir o capital de giro, seja como integralização de novos sócios ou de capital de terceiros.

O relacionamento com o cliente necessita de uma manutenção constante e deve ser feita de maneira profissional. Para isso, o empresário deve ter critérios rígidos de disponibilidade ao crédito a seus clientes, de acordo com a capacidade financeira de cada um, reduzindo, assim, problemas com a inadimplência. 
Para o bom funcionamento das atividades, é fundamental a contratação de pessoal qualificado. Além disso, manter a qualificação profissional com capacitação e cursos é essencial para manter o alto nível dos colaboradores.

Também foi citada pelos contadores a necessidade de se ter uma boa noção de direito tributário e conhecer os fundamentos da contabilidade de custos, para que, assim, possam ser calculados seus custos, preço de venda, margem de contribuição, planejamento tributário, entre outros, diminuindo alguns riscos corridos pelos empresários, sempre contando com o auxílio de um contador.

\section{CONSIDERAÇÕES FINAIS}

A investigação central a presente pesquisa buscou conhecer quais são os fatores determinantes da falência das micro e pequenas empresas da região metropolitana de Florianópolis após a análise dos questionários enviados aos contadores.

Os estudos existentes destacam vários fatores que levam à falência as MPEs, sendo os mais citados: falta de capital de giro; falta de capacitação (nível de escolaridade); incompetência gerencial e má gestão; falta de planejamento estratégico; falta de conhecimento do mercado; não existência de políticas de preço, produtos, propaganda e distribuição; alta carga tributária; falta de mão de obra qualificada; acesso ao crédito; e falta de plano de negócios.

De acordo com a pesquisa, podem-se concluir quais eram os mais citados e, assim, ter uma base de comparação, analisando se sob a ótica dos contadores os fatores já citados foram realmente os precursores da insolvência de tais empresas.

Foi comprovado que a grande maioria dos motivos citados foi aceito e validado pelas hipóteses estudadas. Sendo assim, oito dos dez fatores possuem grande influência sobre o fim dessas MPEs. Porém, dois fatores citados não foram cruciais sob a ótica do contador para a falência das MPEs, entre eles estão a H2 e H7.

A hipótese 2, que afirmava que "quanto menor o nível de escolaridade do(s) empreendedor(es) ou sócio(s), maior a chance de mortalidade", foi refutada pela ótica dos 
contadores pesquisados, desmistificando que quanto maior o estudo do empreendedor antes de abrir o empreendimento, melhor é a gestão.

A hipótese 7, que afirmou que "quanto maior a carga tributária, maior a chance de mortalidade", também foi refutada, contrariando o ponto de vista do empresário que esse é um dos fatores propulsores para a falência, demonstrando que quem trabalha com esse empresário diariamente e tem um conhecimento grande sobre suas finanças afirma que a carga tributária não é fator primário para a sucumbência do mesmo.

É interessante notar, além disso, a sucinta diferença de motivos apresentados entre estudos que tratavam sob o ponto de vista do empresário e sob a ótica do contador. Por mais que o empresário trabalhe diretamente com o contador, ambos possuem opiniões diferenciadas sobre a falência dos mesmos.

Enfim, este trabalho teve a seguinte pergunta de pesquisa: "como identificar e caracterizar, sob a ótica do contador, um conjunto de fatores que podem levar à mortalidade precoce das micro e pequenas empresas estudadas?". Para chegar à resposta de tal pergunta, esta pesquisa teve o seguinte objetivo geral: "analisar, sob a ótica do contador, os fatores determinantes para a mortalidade precoce das micro e pequenas empresas na região metropolitana de Florianópolis".

A importância do assessoramento adequado pelos contadores às MPEs parte do pressuposto de que elas também os afetam, pois são seus clientes e sua fonte de renda. $\mathrm{Na}$ análise dos escritórios respondentes, percebe-se que 80\% possuem, no máximo, 79 clientes e que muitos desses clientes são MPEs, ou seja, a falência dessas reflete diretamente no montante de suas carteiras de clientes.

Por fim, este estudo alcançou seus objetivos respondendo, assim, à sua pergunta de pesquisa e, com isso, pode apontar e indicar caminhos que levarão o futuro empreendedor a ser mais próspero, evitando o grande número de casos de falências de MPEs que assolam o país. 
DECISIVE FACTORS TO MORTALITY OF MICRO AND SMALL COMPANIES IN THE METROPOLITAN AREA OF FLORIANOPOLIS FROM THE STANDPOINT OF THE ACCOUNTANT

\section{ABSTRACT}

The objective of this paper is to analyze under the accountant perspective the determining factors for early mortality of micro and small enterprises in the city of Florianopolis, Brazil. In order to learn more about the aspects that lead companies to succumb, it was conducted a quantitative research. For data collection, a questionnaire was applied to 141 accountants from the metropolitan region of Florianopolis. It was possible to identify that most of the factors cited by the specialized literature is equally important from the accountant perspective. Even so, two factors cited in the specialized literature were not crucial under the perspective of the accountant to the failure of MSE, namely, the education level of the entrepreneur and the tax burden.

Keywords: Bankruptcy. Micro and small enterprises. Accountant.

\section{REFERÊNCIAS}

ADIZES, I. Os ciclos de vida das organizações: como e por que as empresas crescem e morrem e o que fazem a respeito. São Paulo: Pioneira, 1990.

ALVES, M. A. P. et al.(Coord.). Pesquisa: fatores condicionantes e taxa de mortalidade das empresas. Brasília, 1999. Disponível em: <http://www.sebrae.com.br>. Acesso em: 04 ago. 2010.

AZEVEDO, J. H. Como iniciar uma empresa de sucesso. Rio de Janeiro: Qualitymark, 1992.

BALESTRIN, A.; VARGAS, L. M. Redes horizontais de cooperação como estrutura favorável para o desenvolvimento das PMEs. In: ENCONTRO NACIONAL DA ASSOCIAÇÃO DE PÓSGRADUAÇÃO EM ADMINISTRAÇÃO, 27., 2003, Atibaia. Anais... Atibaia: ANPAD, 2003.

BIRLEY, S.; NIKTARI, N. Reasons for business failure. Leadership \& Organization Development Journal, United Kingdom, v. 17, n. 2, p. 52, March. 1996.

BORINELLI, M. L.; BEUREN, I. M. O postulado da continuidade na perspectiva do ciclo de vida organizacional. In: SEMINÁRIO USP DE CONTABILIDADE, 2., 2002, São Paulo. Anais 
eletrônicos....Disponível em:

<http://www.eac.fea.usp.br/congressousp/seminario2/trabalhos/A193.pdf>. Acesso em: 10 abr. 2010.

BRASIL. Lei Complementar no 123, de 14 de dezembro de 2006. Institui o Estatuto Nacional da Microempresa e da Empresa de Pequeno Porte. Disponível em:

<http://www.receita.fazenda.gov.br/legislacao/leiscomplementares/2006/leicp123.htm>.

Acesso em: 05 ago. 2010.

CARDOSO, C. G. Variáveis pertinentes aos empresários que impactam na continuidade de suas micro e pequenas empresas observadas em um escritório contábil. 2007. $86 \mathrm{f}$.

Dissertação (Mestrado em Ciências Contábeis)-Fundação Instituto Capixaba de Pesquisa em Contabilidade, Economia e Finanças, Vitória, 2007.

CASAROTTO FILHO, N.; PIRES, L. H. Redes de pequenas e médias empresas e o desenvolvimento local. São Paulo: Atlas, 1998.

CLEVERLY, W. O. Who is responsible for business failures? Healthcare Financial Management Review, Westchester, v. 56, n. 10, p. 45-51, Oct. 2002.

COCHRAN, A. B. Small business mortality rates: a review of the literature. Journal of Small Business Management, United Kingdom, v. 19, n. 4, p. 50-59, oct. 1981.

COLLIS, J; HUSSEY, R. Pesquisa em administração: um guia prático para alunos de graduação e pós-graduação. 2. ed. Porto Alegre: Bookman, 2005. 339 p.

CUNHA JUNIOR, A. M. Mortalidade e sobrevivência das micro e pequena empresas no Estado da Paraíba. 2009. 103 f. Dissertação (Mestrado em Economia)- Universidade Federal da Paraíba, João Pessoa, 2009.

DA SILVA, J. B. A mortalidade das micro e pequenas empresas. Florianópolis: SEBRAE/SC, 2008.

DA SILVA, Ricardo Luiz. Micro e pequenas empresas: um estudo sobre sua mortalidade prematura. 2002. 326 f. Dissertação (Mestrado em Sistemas de Gestão)-Universidade Federal Fluminense, Niterói, 2002.

DAVIS, H. Business mortality: the shoe manufacturing industry. Harvard Business Review, Boston, v. 17, n. 3, p. 331, spring. 1939.

DE GEUS, A. A empresa viva: como as organizações podem aprender e prosperar e se perpetuar. Trad. de Lenke Peres. 12. ed. Rio do Janeiro: Elsevier, 1998.

DEGEN, J. R. O empreendedor: fundamentos da iniciativa empresarial. São Paulo: McGrawHill, 1989. 
DOLABELA, F. O segredo de Luisa. São Paulo: Cultura, 1999.

DUTRA, I. S. O perfil do empreendedor e a mortalidade de micro e pequenas empresas londrinenses. 2002. 125 f. Dissertação (Mestrado em Administração)-Programa de PósGraduação em Administração das Universidades Consorciadas Estadual de Londrina e Estadual de Maringá, Londrina: 2002.

EDMISTER, R. O. An empirical test of financial ratio analysis for small business failure prediction. Journal of Financial and Quantitative Analysis, United Kingdom, v. 7, n. 2, p. 1477-93, March. 1972.

FELIPPE, M. C. Sobrevivência e mortalidade das pequenas e médias empresas na cidade de São José dos Campos. 2003. 140 f. Dissertação (Mestrado em Administração de Empresas) Departamento de Economia, Contabilidade, Administração e Comércio Exterior da Universidade de Taubaté, Taubaté, 2003.

FILARDI, L. F. Estudo dos fatores contribuintes para a mortalidade precoce de micro e pequenas empresas da cidade de São Paulo. 2006. $170 \mathrm{f}$. Tese (Doutorado em Administração) - Programa de Pós-Graduação em Administração da Universidade de São Paulo, 2006.

FILARDI, L. F.; SANTOS, S. A. . In: ENCONTRO DE ESTUDOS SOBRE EMPREENDEDORISMO E GESTÃO DE PEQUENAS EMPRESAS, 5. 2008, São Paulo. Anais... São Paulo: Mackenzie, 2008.

FISCHMANN, A. A.; ALMEIDA, M. I. R. Planejamento Estratégico na Prática. 2. ed. São Paulo: Atlas, 2009.

GLOBAL ENTREPRENEURSHIP MONITOR. Disponível em: <http://www.gemconsortium.org>. Acesso em: 15 jan. 2011.

Executive Report, Babson College Press, 2009. Disponível em: <http://www.gemconsortium.org/docs/265/gem-2009-global-report>. Acesso em: 15 jan. 2011.

Executive Report, Babson College Press, 2005. Disponível em: $<$ http://www.gemconsortium.org/docs/261/gem-2005-global-report>. Acesso em: 15 jan. 2011.

GIL, A. C. Como elaborar projetos de pesquisa. São Paulo: Atlas, 1991.

GOMES, A. Análise dos modelos de previsão de falência brasileiros. In: ENANPAD, 24., 2000, Florianópolis. Anais... Florianópolis: ANPAD, 2000. 
GONÇALVES, M. F. A pequena empresa e expansão industrial. Lisboa: Associação Industrial Portuguesa, 1994.

HARPER, D. A. Towards a theory of entrepreneurial teams. Journal of Business Venturing, Philadelphia, v. 23, n. 6, p. 613-626, nov. 2008

HOLMES, S.; HASWELL, S. Estimating the business failure rate: a reappraisal. Journal of Small Business Management, United Kingdom, v. 27, n. 3, p. 68, July. 1989.

INSTITUTO BRASILEIRO DE GEOGRAFIA E ESTATÍSTICA. Coordenação de Serviços e Comércio. As micro e pequenas empresas comerciais e de serviços no Brasil 2001. Estudos e Pesquisas: Informação Econômica. II. Série. n. 1. Rio de Janeiro: IBGE, 2003.

IBGE, Instituto Brasileiro de Geografia e Estatística. Condição de vida. 2004. Disponível em: <http://www.ibge.gov.br/home/estatistica/população/condicaodevida>. Acesso em: 02 abr. 2010.

Sala de imprensa. 2004. Disponível em:

<http://www.ibge.gov.br/home/presidencia/noticias/noticia_visualiza.php?id_noticia=234\&i d_pagina=1>. Acesso em: 07 abr. 2010.

IDH - Indicadores de Desenvolvimento Humano. Tabela de Indicadores de Desenvolvimento Humano. Disponível em:

<http://hdr.undp.org/en/media/HDR_2010_PT_Tables_reprint.pdf>. Acesso em: 2 out. 2011.

JUCESC. Disponível em: <http://www.jucesc.sc.gov.br/>. Acesso em: 10 abr. 2010.

KERLINGER, F. N. Metodologia da pesquisa em ciências sociais: um tratamento conceitual. São Paulo: EPU, 1980.

KOTESKI, M. A. As micro e pequenas empresas no contexto econômico brasileiro. Fae Business, Curitiba, n. 8, p. 16-18, maio. 2004.

LEONE, N. M. C. P. G. A dimensão física das pequenas e médias empresas. Revista de Administração de Empresas, São Paulo, v. 31, n. 2, p. 53-59, abr./jun. 1991.

LIMA, A. L. Os riscos do empreendedorismo: a proposta de educação e formação empreendedora. 2008. 131 f. Dissertação (Mestrado em Educação) - Faculdade de Educação da Universidade de São Paulo, São Paulo, 2008.

LIMA, M. V. A.; FILARDI, L. F.; LOPES, A. L. M. Avaliação multicritério do risco percebido dos fatores contribuintes para a mortalidade precoce de micro e pequenas empresas no Brasil. In: SIMPÓSIO DE ADMINISTRAÇÃO DA PRODUÇÃO, LOGÍSTICA E OPERAÇÕES INTERNACIONAIS - SIMPOI, 12., 2009, São Paulo. Anais... São Paulo: FGV-EAESP, 2009. 
LONGENECKER, J. G.; MOORE, C. W.; PETTY, J. W. Administração de pequenas empresas: ênfase na gerência empresarial. São Paulo: Makron Books, 1997.

MAI, A. F. O perfil do empreendedor versus a mortalidade das micro e pequenas empresas comerciais do município de Aracruz/ES. 2006. 153 f. Dissertação (Mestrado em Ciências Contábeis) - Fundação Instituto Capixaba de Pesquisas em Contabilidade, Economia e Finanças - FUCAPE, Vitória, 2006.

MEDINA, E. A. M. Fatores condicionantes de sucesso na gestão de micro e pequena empresa do setor de vestuário da grande Florianópolis. 2002. 117 f. Dissertação (Mestrado em Administração)-Programa de Pós Graduação em Administração da Universidade Federal de Santa Catarina, Florianópolis, 2002.

MEIRA NETO, A. O profissional contábil diante das necessidades decisórias dos empresários e gestores, considerando o ambiente tecnológico atual. São Paulo: Unifecap, 2003. 126p.

NUENO, P. Emprendiendo el arte de crear empresas y sus artistas. Madrid: Deusto S.A. 1995.

ORTIGARA, A. A. Causas que condicionam a mortalidade e/ou o sucesso das micro e pequenas empresas no Estado de Santa Catariana. 2006. 176 f. Tese (Doutorado em Engenharia de Produção)- Programa de Pós-Graduação em Engenharia de Produção da Universidade Federal de Santa Catarina, Florianópolis, 2006.

PASSOS, C. A. K. et al. Empreendedorismo no Brasil:- 2007. Curitiba: IBQP, 2008. Disponível em: <http://www.gemconsortium.org/document.aspx?id=672>. Acesso em: 10 fev. 2011.

PAZOLINI, H. A percepção dos contadores sobre o perfil de sucesso dos micro e pequenos empresários da região do município de Colatina/ES. 2011. 85 f. Dissertação (Mestrado em Ciências Contábeis) - Fundação Instituto Capixaba de Pesquisas em Contabilidade, Economia e Finanças - FUCAPE, Vitória, 2011.

PELISSARI, A. S. O perfil de qualificação profissional dos empresários das pequenas empresas do ramo de confecções da Glória, Vila Velha-ES. 2002. 155 f. Dissertação (Mestrado em Engenharia de Produção)-Programa de Pós-Graduação em Engenharia de Produção da Universidade Federal de Santa Catarina, Florianópolis, 2002.

PORTAL BRASIL. Disponível em:

<http://www.brasil.gov.br/empreendedor/empreendedorismo-hoje/o-mapa-das-micro-epequenas-empresas>. Acesso em: 20 jan. 2012.

RIBEIRO NETO, A. B. Fatores que impactam o desempenho de pequenas empresas. 2008. 378 f. Tese (Doutorado em Engenharia de Produção) - Programa de Pós-graduação em 
Engenharia de Produção/COPPE da Universidade Federal do Rio de Janeiro, Rio de Janeiro, 2008.

RICHARDSON, R. J. Pesquisa social: métodos e técnicas. 3. ed. São Paulo: Atlas, 1999.

SANTOS, S. A.; PEREIRA, H. J. Criando seu próprio negócio: como desenvolver o potencial empreendedor. Brasília: SEBRAE, 1995.

SAUNDERS, M. N. K.; LEWIS, P.; THORNHILL, A. Research methods for business students. England: Pearson Education, 2000.

Research methods for business students. 3. ed. England: Pearson Education, 2003.

SEBRAE. Fatores condicionantes e taxa de mortalidade de empresas. Relatório de pesquisa. Brasília, Ago. 2004. 58 p.

. Fatores condicionantes e taxa de mortalidade de empresas. Relatório de pesquisa. Brasília, Out. 1999. 56 p.

Mortalidade. Disponível em:

<http://www.sebraesp.com.br/conhecendo_mpe/mortalidade>. Acesso em: 11 abr. 2010.

Anuário de trabalho na micro e pequena empresa. 2006. Disponível em:

<http://201.2.114.147/bds/BDS.nsf/572C3CE47D9997DC83257486004E858E/\$File/NT00038 B0A.pdf>. Acesso em: 01 ago. 2011.

Qual a diferença entre falência, concordata e insolvência civil? Disponível em: <http://www.sebraesp.com.br/faq/financas/procedimentos_controles/falencia_concordata _insolvencia>. Acesso em: 24 maio 2010.

. Estudos e pesquisas. Disponível em:

<http://www.sebrae.com.br/customizado/estudos-e-pesquisas>. Acesso em: 05 ago. 2010(b).

SEBRAE. Vox Populi. 2011. Disponível em:

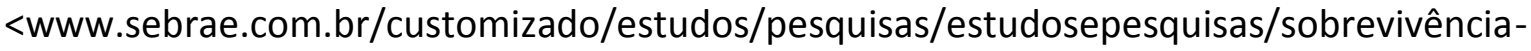
das-micro-e-pequenasempresas>. Acesso em: 12 mai. 2011.

SERASA EXPERIAN. 2010. Disponível em:

<http://www.olhardireto.com.br/noticias/exibir.asp?noticia=Pedidos_de_falencia_de_grand es_empresas_cresceram_69_no_primeiro_trimestre_do_ano\&edt=28\&id=94577 >. Acesso em: 02 abr. 2010.

SILVA, A. C. R. Metodologia da pesquisa aplicada à contabilidade: orientações de estudos, projetos, relatórios, monografias, dissertações, teses. São Paulo: Atlas, 2003. 
SILVA, J. S. Fatores determinantes da mortalidade da micro e pequena empresa industrial de criação e abate de aves, na grande Natal/RN. 1999. 128 f. Dissertação (Mestrado em Administração) - Universidade Federal do Rio Grande do Norte, Natal, 1999.

TACHIZAWA, T.; FARIA, M. S. Criação de novos negócios gestão de micro e pequenas empresas. Rio de Janeiro: FGV, 2002.

VALE, G. M. V. et al. (Coord.). Fatores condicionantes da mortalidade de empresas: pesquisa piloto realizada em Minas Gerais. Belo Horizonte: SEBRAE, 1998.

XEYLA, R.; GOUTHIER, M. Investir em capacitação é o melhor negócio. 2008. Disponível em: $<$ http://www.sebrae-

sc.com.br/novos_destaques/oportunidade/default.asp?materia=15193>. Acesso em: $10 \mathrm{abr}$. 2010.

ZIMMERER, T. W.; SCARBOROUGH, N. M. Essentials of entrepreneurship and small business management. 2. ed. New Jersey: Prentice Hall, 1998.

Essentials of small business management. New York: Macmillan College, 1994.

YONEMOTO, H. W. Os fatores externos e internos e a sua relação com o êxito ou fracasso das empresas de pequena dimensão. 1998. Dissertação (Mestrado em Engenharia de Produção) Programa de Pós-Graduação em Engenharia de Produção da Universidade Federal de Santa Catarina, Florianópolis, 1998. 